\title{
Estimation of Energy and Protein Requirements of Arabic Hens during Rearing Period by Free Choice Feeding
}

\author{
Syafwan*, Noferdiman, S. Zubaida, T. M. Pasaribu, \& Adrizal \\ Faculty of Animal Science, University of Jambi \\ Jalan Raya Jambi-Ma. Bulian KM. 15 Mendalo Darat, Jambi 36361, Indonesia \\ *Corresponding author: syafwan@unja.ac.id \\ (Received 11-05-2020; Revised 12-08-2020; Accepted 26-08-2020)
}

\begin{abstract}
The present experiment was conducted to estimate the metabolizable energy (ME) and crude protein (CP) requirements of female Arabic chickens under a semi-scavenging system from starter to first egg-laying age. Two hundred and forty-five day-old chicks were allotted into 12 sheltered pens with 20 chicks each. They were offered either control or choice diet and replicated six times. The control group was offered a control diet based on the Hy-line Brown Nutrient Requirements Standard, whereas the choice group was offered a control diet (starter period: $2910 \mathrm{kcal}$ of ME$/ \mathrm{kg}$ and $19.7 \%$ of CP; grower period: $2854 \mathrm{kcal}$ of ME/ $\mathrm{kg}$ and $17.5 \%$ of CP; developer period: $2754 \mathrm{kcal}$ of ME/kg and $16.0 \%$ of CP; prelaying period: $2776 \mathrm{kcal}$ of ME/ $\mathrm{kg}$ and $16.5 \%$ of CP; and laying period: $2814 \mathrm{kcal}$ of ME/ $\mathrm{kg}$ and $18.4 \%$ of $\mathrm{CP}$ ) together with four other diets (high energy-high protein [3101 kcal of ME/kg and $23.0 \%$ of CP], high energy-low protein [3133 kcal of ME $/ \mathrm{kg}$ and $14.3 \%$ of CP, low energy-high protein [2638 kcal of $\mathrm{ME} / \mathrm{kg}$ and $23.4 \%$ of $\mathrm{CP}$ ], and low energy-low protein [2677 kcal of ME/kg and $14.6 \%$ of CP]). Data were analyzed using Proc Mixed of SAS. Results showed that feed intake was significantly lower in choice dietary treatments in all periods, except in the starter period. $M E$ and $C P$ intakes were similar $(p>0.05)$ in all periods. However, ME and CP concentrations in the diet consumed were higher $(\mathrm{p}<0.05)$ in choice dietary treatment in all periods, except CP concentration in the starter period. BWG started to be higher $(\mathrm{p}<0.05)$ in choice dietary treatment during the developer and pre-laying period. The onset of laying was two days early in choice-fed birds. It can be concluded that free choice feeding on a diet varying in energy and protein had a beneficial effect on the growth rate of female Arabic hens by consuming more a high energy-high protein and a high energy-low protein diet. $\mathrm{ME}$ and $\mathrm{CP}$ requirements of Arabic hens for starter period were $3026 \mathrm{kcal}$ of ME/kg and 18.8\%, for grower period were $3081 \mathrm{kcal}$ of ME/ $\mathrm{kg}$ and $18.4 \%$, for developer period were $3091 \mathrm{kcal}$ of $\mathrm{ME} / \mathrm{kg}$ and $18.5 \%$, and for pre-laying period were $3072 \mathrm{kcal}$ of $\mathrm{ME} / \mathrm{kg}$ and $18.8 \%$ to faster the onset of laying.
\end{abstract}

Keywords: self-selection; Arabic chicken; energy intake; protein intake; tropic

\section{INTRODUCTION}

A specific breed of native chicken that has been recognized having a high egg production is Arabic chicken (Hartawan \& Dharmayanti, 2016). Therefore, Arabic hens could be realized to increase the contribution to national egg production in the future. Director General of Livestock and Animal Health (2019) reported that the egg production of local village chickens decreased $3.9 \%$ from 2017 to 2018 and increased 3.7\% from 2018 to 2019. The contribution of the production of egg by local village chicken to the national egg production increased only $0.08 \%$ from 2018 to 2019 . The poor egg contribution during the last year indicates that the productive performance of local chickens is still low, although the rearing system has been changed to semi and intensive system. One of the main constraints to increase egg production in these chickens might be the nutrient requirements are not suitable for them.
Limited information is available in the literature related to local chicken's metabolizable energy (ME) and crude protein $(\mathrm{CP})$ requirements. Kristina Dewi et al. (2015) reported that the growth rate and feed conversion ratio (FCR) of native chicken in Bali during the starter phase (0-8 weeks) increased with an increase in dietary energy (3100 kcal ME/kg) and CP (22\%). Raphulu and van Rensburg (2018) reported that crude protein (CP) in the diet about $17 \%$ with $2627 \mathrm{kcal} \mathrm{AME} / \mathrm{kg}$ for starter period (0-6 weeks) and 15\% with $2866 \mathrm{kcal} \mathrm{AME/kg}$ for grower period (7-17 weeks) are needed to optimize the growth rate and FCR for unsex local chicken in South Africa. Perween et al. (2016) reported that the backyard breed, namely Vanaraja developed by the Project of Directorate of Poultry (PDP), Hyderabad that was very well acclimatized to village climate in India have a better body weight gain and FCR with $17 \%$ and $19 \%$ $\mathrm{CP}$ combined with $3000 \mathrm{kcal} \mathrm{ME} / \mathrm{kg}$. These studies suggested that the nutrient requirements of local village chickens are still not conclusive. 
Self-selection feeding is another strategy to get the appropriate $\mathrm{ME}$ and $\mathrm{CP}$ requirements for birds in the tropics. Self-selection feeding permits the birds to choose the nutrient requirements from a set of nutrients suitable for their growth and physiological development conditions. Cruz et al. (2005) and Syafwan et al. (2012) reported that broiler was able to meet the nutrient requirements by offering various ingredients with different contents of protein and energy at the high temperature indicated by a similar BW gain as a control diet. In laying hens, only hens fed with the most concentrated diets were able to meet the recommended daily protein intake at high temperatures when offering diets varying in energy and nutrient density to overcome the nutritional stresses associated with the onset of laying and with periods of high temperature although egg mass output remained low with the highest $\mathrm{ME}$ and protein intakes (Daghir, 2008). However, it is not known what kind of diet the Arabic chicken would select from various diets varying in protein and energy contents to compose their nutrient requirements that suitable with their physiological development conditions. This selection may result in a faster growth rate and onset of laying compared with a control diet.

The objectives of this study were (1) to determine the nutrient composition of diets consumed by Arabic female chicks when they were offered various choices of diet varying in energy and protein contents; (2) to determine what are the protein and energy requirements for Arabic female chicks during the growing period; (3) and to determine the time of onset of laying in Arabic chicks when they were given a choice fed diets.

\section{MATERIALS AND METHODS}

\section{Animal Care, Birds, and Housing}

All experiments were approved by the Ethical Clearance Committee of Animal Science Faculty, University of Jambi, with number 001/UN21.7/ ECC/2021. A total of 240 five-day-old female Silver Arabic hens were used in this research. This chicken is a specific breed of native chicken for layer purposes (Hartawan \& Dharmayanti, 2016). The experimental chicks were allotted to 12 sheltered pens with 20 chicks each. The pens were covered with netted nylon. Two meters of the pen were inside the barn and 3 meters of the pen were outside the barn. The width and height of pen were similar inside and outside the barn $(1.75 \times 2$ $\mathrm{m})$. The pen's floor inside the barn was covered with sand as a litter and the pen's floor outside the barn was soil. The house was an open-sided barn and the hens could go in and out of the pen and enter the yard freely.

Each diet was placed in a separate feed trough. The positions of the feeding trough were changed every day randomly to avoid the habituation of hens. Bell-shaped drinkers were used for drinking water. Feeds and drinking ware were offered ad libitum.

Temperature $(\mathrm{T})$ and relative humidity $(\mathrm{RH})$ were recorded in the morning $(07: 00 \mathrm{~h})$, the day $(12: 00 \mathrm{~h})$, and the afternoon (17:00 h) by thermo-hygrometer. After two weeks of age, half of the pen high inside the barn was covered with black plastic and the chicks were warmed with an electric bulb.

\section{Experimental Design and Treatments}

A completely randomized design with 2 treatments and 6 replicates (pens) of 20 chicks were used in this experiment. The no-choice hens offered a control ration containing $\mathrm{ME}, \mathrm{CP}$, and other nutrients for 4 phases (starter [0-6 weeks of age], grower [7-12 weeks of age], developer [13-15 weeks of age], pre-laying [16-17 weeks of age], and laying [18 weeks of age]) as were recommended by The Hy-line Brown Commercial Management Guide (HyLine, 2011). This recommendation was chosen because the bodyweight of the Arabic chick was $10 \%$ lower than that of the targeted mean BW of Hy-line Brown chick. To be save, the pre-laying control feed was stopped at the $17^{\text {th }}$ week, although the hens did not lay eggs yet and continued with laying standard feed from the $18^{\text {th }}$ week of age until they laid the eggs.

The choice groups were given a control diet (starter period: $2910 \mathrm{kcal}$ of $\mathrm{ME} / \mathrm{kg}$ and $19.7 \%$ of $\mathrm{CP}$; grower period: $2854 \mathrm{kcal}$ of $\mathrm{ME} / \mathrm{kg}$ and $17.5 \%$ of $\mathrm{CP}$; developer period: $2754 \mathrm{kcal}$ of $\mathrm{ME} / \mathrm{kg}$ and $16.0 \%$ of $\mathrm{CP}$; pre-laying period: $2776 \mathrm{kcal}$ of $\mathrm{ME} / \mathrm{kg}$ and $16.5 \%$ of $\mathrm{CP}$; and laying period: $2814 \mathrm{kcal}$ of $\mathrm{ME} / \mathrm{kg}$ and $18.4 \%$ of $\mathrm{CP}$ ) and four other diets (high energy-high protein, HEHP [3101 kcal of $\mathrm{ME} / \mathrm{kg}$ and $23.0 \%$ of $\mathrm{CP}]$, high energy-low protein, HELP [3133 $\mathrm{kcal}$ of ME/kg and $14.3 \%$ of CP], low energy-high protein, LEHP [2638 kcal of ME/ $\mathrm{kg}$ and $23.4 \%$ of $\mathrm{CP}]$, and low energy-low protein, LELP diet [2677 kcal of $\mathrm{ME} / \mathrm{kg}$ and $14.6 \%$ of $\mathrm{CP}])$. All the diets were offered in a mash form. The nutrients contents of the diets are presented in Table 1. These four diets differed from the control diet in the energy and protein contents, while the other nutrients were almost identical.

Feed intake (FI) per pen was recorded by weighing the feed offered and feed residues on a weekly basis. $\mathrm{ME}$ and $\mathrm{CP}$ intakes were calculated from the intake of each of the five diets times the content of ME and CP in each diet, then divided by $1000(\mathrm{~g} / \mathrm{kg})$ and were used to calculate the ME and $\mathrm{CP}$ utilizations. The concentrations of $\mathrm{ME}$ and $\mathrm{CP}$ in the diet intake were calculated from the ME and CP intakes divided by FI times 1000 (g/kg) (Syafwan et al., 2012). BW gain was determined by weighing the bird weekly. The weights of birds that died or had to be culled were accounted for in their mean weekly BW gains. Protein (g/g BW gain) and energy utilization (ME/g BW gain) per pen were calculated from protein and energy intakes divided by BW gain, respectively (Syafwan et al., 2012).

\section{Statistical Analysis}

Data were analyzed according to the method described by Syafwan et al. (2012) by using PROC MIXED in SAS. Since the data were taken repeatedly on the same animals, they could not be considered as separate units of observation (Littell et al., 1998; Walter et al., 2018). In the analysis, weeks of age or age phase were used as the time factor, and pen was considered an additional random effect. 
Table 1. The ingredients $(\mathrm{g} / \mathrm{kg})$ composition and calculated nutrients content of dietary treatments

\begin{tabular}{|c|c|c|c|c|c|c|c|c|c|}
\hline \multirow[b]{2}{*}{ Ingredients } & \multicolumn{5}{|c|}{ Control feed } & \multicolumn{4}{|c|}{ Self-selection feed } \\
\hline & $\begin{array}{c}\text { Starter } \\
(0-6 \text { week })\end{array}$ & $\begin{array}{c}\text { Grower } \\
\text { (7-12 week) }\end{array}$ & $\begin{array}{c}\text { Developer } \\
\text { (13-15 week) }\end{array}$ & $\begin{array}{l}\text { Pre-laying } \\
\text { (16-17 week) }\end{array}$ & $\begin{array}{c}\text { Laying } \\
\text { ( } \geq 18 \text { week) }\end{array}$ & $\mathrm{HEHP}^{3}$ & $\mathrm{HELP}^{4}$ & LEHP $^{5}$ & LELP $^{6}$ \\
\hline Rice bran & 95.0 & 140.0 & 329.5 & 199.2 & 160.0 & 0.0 & 174.0 & 243.0 & 366.0 \\
\hline Corn & 498.5 & 540.0 & 350.0 & 450.0 & 320.0 & 433.0 & 550.0 & 287.0 & 360.0 \\
\hline Soybean meal & 290.0 & 234.6 & 230.0 & 220.0 & 251.5 & 355.0 & 130.0 & 405.0 & 200.0 \\
\hline Fish meal & 51.0 & 39.0 & 20.0 & 40.0 & 82.0 & 90.0 & 50.0 & 40.0 & 0.0 \\
\hline Salt & 3.3 & 3.0 & 3.5 & 2.8 & 3.0 & 2.0 & 2.0 & 2.0 & 3.0 \\
\hline Top Mix ${ }^{1}$ & 5.0 & 5.0 & 5.0 & 5.0 & 5.0 & 5.0 & 5.0 & 5.0 & 5.0 \\
\hline Dicalcium phosphate & 6.5 & 8.0 & 12.0 & 6.0 & 2.0 & 0.0 & 3.0 & 3.0 & 12.0 \\
\hline Ca-carbonate & 15.0 & 20.0 & 30.0 & 52.0 & 95.0 & 15.0 & 20.0 & 15.0 & 50.0 \\
\hline DL-Methionine & 0.7 & 0.4 & 0.0 & 0.0 & 1.5 & 0.0 & 2.0 & 0.0 & 2.0 \\
\hline L-lysine HCL & 0.0 & 0.0 & 0.0 & 0.0 & 0.0 & 0.0 & 4.0 & 0.0 & 2.0 \\
\hline Palm oil & 35.0 & 10.0 & 20.0 & 25.0 & 80.0 & 100.0 & 60.0 & 0.0 & 0.0 \\
\hline Total & 1000 & 1000 & 1000 & 1000 & 1000 & 1000 & 1000 & 1000 & 1000 \\
\hline \multicolumn{10}{|c|}{ Nutrient composition (calculated) } \\
\hline Dry matter (\%) & 88.6 & 90.8 & 92.1 & 91.3 & 85.2 & 92.4 & 82.6 & 86.0 & 92.5 \\
\hline $\mathrm{CP}(\%)$ & 19.7 & 17.5 & 16.0 & 16.5 & 18.4 & 23.4 & 23.0 & 14.3 & 14.6 \\
\hline $\mathrm{ME}(\mathrm{kcal} \mathrm{ME} / \mathrm{kg})^{2}$ & 2910 & 2854 & 2754 & 2776 & 2814 & 2638 & 3101 & 3133 & 2677 \\
\hline $\mathrm{EE}(\%)$ & 4.05 & 4.94 & 8.77 & 4.66 & 4.78 & 7.00 & 1.88 & 4.96 & 9.01 \\
\hline CF $(\%)$ & 4.30 & 4.54 & 5.01 & 4.69 & 4.11 & 4.53 & 3.90 & 4.65 & 4.77 \\
\hline Lysine (\%) & 1.25 & 1.06 & 1.02 & 1.07 & 1.28 & 1.53 & 1.56 & 1.24 & 1.03 \\
\hline Methionine (\%) & 0.47 & 0.40 & 0.35 & 0.38 & 0.56 & 0.45 & 0.48 & 0.52 & 0.47 \\
\hline Met+Cys (\%) & 0.81 & 0.71 & 0.65 & 0.68 & 0.88 & 0.86 & 0.87 & 0.78 & 0.76 \\
\hline $\mathrm{Ca}(\%)$ & 1.02 & 1.19 & 1.57 & 2.52 & 4.24 & 0.95 & 1.06 & 1.11 & 2.31 \\
\hline NPP (\%) & 0.80 & 0.85 & 1.04 & 0.85 & 0.79 & 0.93 & 0.62 & 0.76 & 1.10 \\
\hline $\mathrm{Na}(\%)$ & 0.45 & 0.44 & 0.45 & 0.48 & 0.46 & 0.39 & 0.45 & 0.35 & 0.41 \\
\hline
\end{tabular}

Note: ${ }^{1}=$ Composition of $1 \mathrm{~kg}$ Top Mix: vitamin A (retinyl acetate) 12,000 IU; vitamin D3 (cholecalciferol) 2,000 IU; vitamin E (dl- $\alpha$-tocopherol) $8.0 \mathrm{mg}$; vitamin K $2.0 \mathrm{mg}$; vitamin B1 (thiamin) $2.0 \mathrm{mg}$; vitamin B2 (riboflavin) $5.0 \mathrm{mg}$; vitamin B6 (pyridoxine- $\mathrm{HCl}$ ) $0.5 \mathrm{mg}$, vitamin B12 (cyanocobalamin) $12 \mathrm{mg}$; vitamin C $25 \mathrm{mg}$; niacin $40 \mathrm{mg}$; vitamin B5 (d-pantothenic acid) $6.0 \mathrm{mg}$; choline chloride $10 \mathrm{mg}$; methionine $30 \mathrm{mg}$; lysine $30 \mathrm{mg}$; iron $20 \mathrm{mg}$; copper $4 \mathrm{mg}$; manganese $120 \mathrm{mg}$; zinc $100 \mathrm{mg}$; cobalt $0.2 \mathrm{mg}$; iodine $0.2 \mathrm{mg}$; zinc bacitracin $21 \mathrm{mg}$, and santoquin (antioxidant) $10 \mathrm{mg}$. $2=$ Metabolisable energy was calculated by determining (combustion) gross energy of the entire diet multiplied with a ME/GE-conversion factor (0.725); ${ }^{3}=\mathrm{HEHP}$ (high energy-high protein diet $\left(3101 \mathrm{kcal}\right.$ of ME $/ \mathrm{kg}$ and $23.0 \mathrm{~g}$ of $\mathrm{CP} / \mathrm{kg}$ ); ${ }^{4}=\mathrm{HELP}$ (high energy-low protein diet (3133 kcal of $\mathrm{ME} / \mathrm{kg}$ and $14.3 \mathrm{~g}$ of $\mathrm{CP} / \mathrm{kg}$ ); ${ }^{5}=\mathrm{LEHP}$ (low energy-high protein $\operatorname{diet}\left(2638 \mathrm{kcal}\right.$ of ME $/ \mathrm{kg}$ and $23.4 \mathrm{~g}$ of $\mathrm{CP} / \mathrm{kg}$ ); ${ }^{6}=\mathrm{LELP}$ (low energy-low protein $\operatorname{diet}(2677 \mathrm{kcal}$ of $\mathrm{ME} / \mathrm{kg}$ and $14.6 \mathrm{~g}$ of $\mathrm{CP} / \mathrm{kg}$ ).

A probability level less than $5 \%$ was considered to be statistically significant. Means were compared by pairwise comparison using the Least Significant Difference when the main effects or their interactions were significant. Means of significant effects were separated using the PDIFF option with PDMIX800 SAS macro at the $p<0.05$ level (Syafwan et al., 2012; Naseem and King, 2020). The Kenward-Roger method was used for computing the denominator $\mathrm{df}$ for the tests of main effects. The best covariance structure was based on the corrected Akaike Information Criteria (AICC).

For every period, the best covariance structures were as follows: Starter period: Simple covariance structure fit the data best for $\mathrm{CP}$ utilization. The first order ante-dependence covariance structure [ANTE(1)] fit the data best for FI and energy intake. The heterogeneous autoregressive covariance structure $[\mathrm{ARH}(1)]$ fit the data best for $\mathrm{CP}$ intake, concentration of $\mathrm{CP}$, as well as ME and ME utilization. Autoregressive covariance structure $[A R(1)]$ fit the data best for BWG. Grower period: Simple covariance structure fi the data best for $\mathrm{FI}, \mathrm{CP}$, and ME intake. ANTE(1) fits the data best for BWG, the concentration of $\mathrm{CP}$, and $\mathrm{ME}$. $\mathrm{ARH}(1)$ fits the data best for $\mathrm{CP}$ utilization and ME utilization. Developer period: Simple covariance structure fit the data best for the concentration of ME. ANTE(1) fits the data best for BWG and ME utilization. ARH(1) fits the data best for FI, CP, ME intake, CP concentration, and CP utilization. Pre-laying period: Simple covariance structure fit the data best for BWG. ARH(1) fits the data best for the rest of the parameters.

\section{RESULTS}

\section{Environmental Condition}

During the experimental period, the average temperature and humidity from 1 to 22 weeks of treatment that were measured at $07.00 \mathrm{~h}, 12.00 \mathrm{~h}$, and $17.00 \mathrm{~h}$ were $24.2 \pm 0.8^{\circ} \mathrm{C}$ and $78.7 \pm 3.8 \%, 30.4 \pm 2.2^{\circ} \mathrm{C}$ and $54.1 \pm 7.7 \%$, as well as $28.7 \pm 2.2^{\circ} \mathrm{C}$ and $60.8 \pm 8.6 \%$, respectively.

\section{Hens Performance}

The mortality of birds during the experimental period was $3.8 \%$. All performance data in the tables were corrected for mortality on a weekly basis. 
Starter period. Table 2 a presents the probability values of all parameters and Table 3 presents the differences in weekly performance of the hens with different dietary treatments.

There was no significant effect of treatments on feed intake (FI) of the chicks (Table 2a). The treatments did not affect protein and energy intakes (Table 2a). Feed intake, as well as protein and energy intakes were affected by the weeks of age (Table 2a and 3) and increased over time (Figure 1). There were interaction effects between dietary treatments and weeks of age on feed, protein, and energy intakes (Table 2a). Interaction between dietary treatments and weeks of age showed that the differences were significantly higher in 3 weeks of age for feed and energy intakes, but protein intakes were significantly higher during the last two weeks of the starter period for both dietary treatments (Figure 2).

BWG was not affected by the feeding method, but BWG was affected by the weeks of age during the starter period (Table 2a and 3). BWG increased by the increased age of chicks (Figure 1). However, there was no interac- tion effect between dietary treatments and weeks of age during the starter period on BWG (Table 2a).

$\mathrm{CP}$ and $\mathrm{ME}$ concentrations were affected by the dietary treatment (Table 2a). CP and ME concentrations were significantly higher in the choice-fed hens than control-fed chicks (Table 3). CP and ME concentrations were affected by the weeks of age during the starter period (Table 2a). CP concentration declined sharply after the $3^{\text {rd }}$ week of age until the $6^{\text {th }}$ week (Figure 1 ). ME concentration increased from the $1^{\text {st }}$ week of age until the $6^{\text {th }}$ week (Figure 1). There were interaction effects between dietary treatments and weeks of age on CP and ME concentrations (Table 2a). Interaction between the dietary treatments and weeks of age during the starter showed that $\mathrm{CP}$ concentration in choice-fed chicks was significantly lower from weeks 4 onward in the trial. However, ME concentration was much higher in choicefed hens from the beginning of the trial (Figure 2).

$\mathrm{CP}$ and ME utilizations were not influenced by the dietary treatments (Table 2a). However, CP utilization was higher in choice-fed chicks compared with control-

Table 2. Probability values of main effects and interaction between dietary treatment ${ }^{1}$ and week for different traits

\begin{tabular}{|c|c|c|c|c|}
\hline Phase & Variables & Treatment & Week & Treatment*Week \\
\hline \multirow[t]{8}{*}{ A. Starter period } & Feed intake (g/hen/week) & 0.774 & $<0.001$ & 0.023 \\
\hline & Protein intake (g of $\mathrm{CP} /$ hen /week) & 0.15 & $<0.001$ & $<0.001$ \\
\hline & Energy intake (kcal of ME/kg/hen/week) & 0.449 & $<0.001$ & $<0.001$ \\
\hline & BWG (g/hen/week) & 0.976 & $<0.001$ & 0.121 \\
\hline & Protein concentration $(\mathrm{g} / \mathrm{kg})$ & $<0.001$ & $<0.001$ & $<0.001$ \\
\hline & Energy concentration (kcal ME/kg) & $<0.001$ & $<0.001$ & $<0.001$ \\
\hline & $\mathrm{CP}$ utilization (g of CP/g BWG) & 0.122 & $<0.001$ & $<0.001$ \\
\hline & Energy utilization (kcal of ME/g BWG) & 0.999 & $<0.001$ & 0.01 \\
\hline \multirow[t]{8}{*}{ B. Grower period } & Feed intake (g/hen/week) & $<0.001$ & $<0.001$ & 0.187 \\
\hline & Protein intake (g of $\mathrm{CP} /$ hen /week) & 0.511 & $<0.001$ & 0.173 \\
\hline & Energy intake (kcal of ME/kg/hen/week) & 0.653 & $<0.001$ & 0.144 \\
\hline & BWG (g/hen/week) & 0.657 & 0.01 & 0.148 \\
\hline & Protein concentration $(\mathrm{g} / \mathrm{kg})$ & $<0.001$ & 0.043 & 0.043 \\
\hline & Energy concentration (kcal ME/kg) & $<0.001$ & 0.01 & 0.01 \\
\hline & CP utilization (g of CP/g BWG) & 0.27 & 0.012 & 0.281 \\
\hline & Energy utilization (kcal of ME/g BWG) & 0.455 & 0.015 & 0.425 \\
\hline \multirow[t]{8}{*}{ C. Developer period } & Feed intake (g/hen/week) & $<0.001$ & 0.002 & 0.006 \\
\hline & Protein intake (g of $\mathrm{CP} /$ hen /week) & 0.46 & 0.002 & 0.059 \\
\hline & Energy intake (kcal of ME/kg/hen/week) & 0.096 & 0.002 & 0.007 \\
\hline & BWG (g/hen/week) & 0.035 & 0.006 & 0.701 \\
\hline & Protein concentration $(\mathrm{g} / \mathrm{kg})$ & $<0.001$ & 0.18 & 0.18 \\
\hline & Energy concentration (kcal ME/kg) & $<0.001$ & 0.42 & 0.42 \\
\hline & $\mathrm{CP}$ utilization (g of CP/g BWG) & 0.156 & 0.002 & 0.24 \\
\hline & Energy utilization (kcal of ME/g BWG) & 0.103 & $<0.001$ & 0.197 \\
\hline \multirow[t]{8}{*}{ D. Pre-laying period } & Feed intake (g/hen/week) & 0.017 & $<0.001$ & 0.017 \\
\hline & Protein intake (g of $\mathrm{CP} /$ hen /week) & 0.642 & $<0.001$ & 0.001 \\
\hline & Energy intake (kcal of ME/kg/hen/week) & 0.25 & $<0.001$ & $<0.001$ \\
\hline & BWG (g/hen/week) & 0.023 & $<0.001$ & 0.069 \\
\hline & Protein concentration $(\mathrm{g} / \mathrm{kg})$ & $<0.001$ & $<0.001$ & $<0.001$ \\
\hline & Energy concentration (kcal ME/kg) & $<0.001$ & $<0.001$ & $<0.001$ \\
\hline & $\mathrm{CP}$ utilization (g of CP/g BWG) & 0.108 & $<0.001$ & 0.096 \\
\hline & Energy utilization (kcal of ME/g BWG) & 0.258 & $<0.001$ & 0.134 \\
\hline
\end{tabular}

Note: ${ }^{1}=$ Control diet (a. starter diet: 0- $6 \mathrm{w}=2910 \mathrm{kcal}$ of ME $/ \mathrm{kg}$ and $19.7 \mathrm{~g}$ of $\mathrm{CP} / \mathrm{kg}$; b. grower diet: $7-12 \mathrm{w}=2854 \mathrm{kcal}$ of $\mathrm{ME} / \mathrm{kg}$ and $17.5 \mathrm{~g}$ of $\mathrm{CP} / \mathrm{kg}$; . developer diet: 13-15 w= $2777 \mathrm{kcal}$ of ME $/ \mathrm{kg}$ and $16.1 \mathrm{~g}$ of $\mathrm{CP} / \mathrm{kg}$; d. pre-laying diet: $16-17 \mathrm{w}=2797 \mathrm{kcal}$ of ME $/ \mathrm{kg}$ and $16.5 \mathrm{~g}$ of $\mathrm{CP} / \mathrm{kg}$; and e. laying diet: $\geq 18 \mathrm{w}=2814 \mathrm{kcal}$ of ME $/ \mathrm{kg}$ and $18.4 \mathrm{~g}$ of CP $/ \mathrm{kg}$ ). Self-selection feed ( $\mathrm{a}=$ the control feed, $\mathrm{b}=\mathrm{HEHP}$ (high energy- high protein diet (3101 $\mathrm{kcal}$ of ME/kg and $23.0 \mathrm{~g}$ of $\mathrm{CP} / \mathrm{kg}$ ); c= HELP (high energy-low protein diet (3133 kcal of ME/kg and $14.3 \mathrm{~g}$ of CP/kg); d= LEHP (low energy-high protein diet (2638 kcal of ME/kg and $23.4 \mathrm{~g}$ of $\mathrm{CP} / \mathrm{kg}$ ); e= LELP (low energy-low protein diet (2677 kcal of ME/kg and $14.6 \mathrm{~g}$ of CP/kg). 
Table 3. Least square means of performance variables in local female chickens from 1 to 6 week of age as affected by dietary treatment ${ }^{1}$

\begin{tabular}{|c|c|c|c|c|c|c|c|}
\hline \multirow{2}{*}{ Variables } & \multicolumn{7}{|c|}{ Week } \\
\hline & 1 & 2 & 3 & 4 & 5 & 6 & Average \\
\hline \multicolumn{8}{|c|}{ Feed intake (g/bird/week) } \\
\hline Control & 69.3 & 112.8 & $144.3^{\mathrm{a}}$ & 159.4 & 238 & 293.7 & 169.6 \\
\hline Self-Selection & 69.0 & 110.7 & $164.0^{\mathrm{b}}$ & 173.7 & 219.4 & 274.2 & 168.5 \\
\hline SEM & 2.28 & 3.31 & 5.92 & 8.12 & 6.85 & 7.33 & 2.60 \\
\hline \multicolumn{8}{|c|}{ Protein intake (g of $\mathrm{CP} /$ bird/week) } \\
\hline Control & 13.7 & 22.3 & 28.5 & 31.4 & $46.9^{\mathrm{a}}$ & $57.9^{a}$ & $33.4^{\mathrm{a}}$ \\
\hline Self-Selection & 13.4 & 22.4 & 32.4 & 31.6 & $38.5^{\mathrm{b}}$ & $49.1^{\mathrm{b}}$ & $31.2^{\mathrm{b}}$ \\
\hline SEM & 0.41 & 0.78 & 1.54 & 1.55 & 1.34 & 1.78 & 0.66 \\
\hline \multicolumn{8}{|c|}{ Energy intake (kcal of ME/kg/bird/week) } \\
\hline Control & 201.7 & 328.4 & 419.9 & 463.9 & 692.5 & 854.8 & 493.6 \\
\hline Self-Selection & 203.8 & 332.4 & $497.2^{\mathrm{a}}$ & 525.8 & 674.2 & 841.6 & 512.5 \\
\hline SEM & 6.71 & 9.70 & $16.53^{\mathrm{b}}$ & 24.79 & 20.05 & 22.13 & 7.73 \\
\hline \multicolumn{8}{|l|}{ BWG (g/bird/week) } \\
\hline Control & 36.2 & 48.6 & 56.6 & 62.3 & 80.4 & $68.6^{\mathrm{a}}$ & 58.8 \\
\hline Self-Selection & 35.6 & 45.4 & 51.6 & 58.9 & 73.3 & $87.6^{\mathrm{b}}$ & 58.7 \\
\hline SEM & 5.15 & 5.15 & 5.15 & 5.15 & 5.15 & 5.15 & 1.34 \\
\hline \multicolumn{8}{|c|}{ Protein concentration ( $\mathrm{g}$ of $\mathrm{CP} / \mathrm{kg}$ ) } \\
\hline Control & 197.2 & 197.2 & 197.2 & $197.2^{\mathrm{a}}$ & $197.2^{\mathrm{a}}$ & $197.2^{\mathrm{a}}$ & $197.2^{\mathrm{a}}$ \\
\hline Self-Selection & 194.7 & 202.4 & 196.8 & $182.0^{\mathrm{b}}$ & $175.7^{\mathrm{b}}$ & $178.9^{\mathrm{b}}$ & $188.4 \mathrm{~b}$ \\
\hline SEM & 0.83 & 2.89 & 2.19 & 2.73 & 2.04 & 2.78 & 1.46 \\
\hline \multicolumn{8}{|c|}{ Energy concentration (kcal of ME/kg) } \\
\hline Control & $2910.4^{\mathrm{a}}$ & $2910.4^{a}$ & $2910.4^{a}$ & $2910.4^{a}$ & $2910.4^{a}$ & $2910.4^{\mathrm{a}}$ & $2910.4^{\mathrm{a}}$ \\
\hline Self-Selection & $2951.8^{\mathrm{b}}$ & $3003.5^{b}$ & $3033.5^{\mathrm{b}}$ & $3026.2^{b}$ & $3072.9^{b}$ & $3069.3^{b}$ & $3026.2^{\mathrm{b}}$ \\
\hline SEM & 5.63 & 2.84 & 10.92 & 6.17 & 2.70 & 3.49 & 2.41 \\
\hline \multicolumn{8}{|c|}{ Utilization of $\mathrm{CP}$ ( $\mathrm{g}$ of $\mathrm{CP} / \mathrm{g}$ BWG) } \\
\hline Control & 0.38 & 0.46 & $0.51^{\mathrm{a}}$ & 0.51 & 0.66 & 0.93 & 0.57 \\
\hline Self-Selection & 0.38 & 0.49 & $0.63^{\mathrm{b}}$ & 0.54 & 0.53 & 0.57 & 0.52 \\
\hline SEM & 0.06 & 0.06 & 0.06 & 0.06 & 0.06 & 0.06 & 0.02 \\
\hline \multicolumn{8}{|c|}{ Utilization of energy (kcal of ME/g BWG) } \\
\hline Control & 5.65 & $6.76^{\mathrm{a}}$ & $7.47^{\mathrm{a}}$ & $7.50^{\mathrm{a}}$ & 9.78 & $13.68^{\mathrm{a}}$ & 8.47 \\
\hline Self-Selection & 5.76 & $7.35^{\mathrm{b}}$ & $9.65^{\mathrm{b}}$ & $9.07^{\mathrm{b}}$ & 9.21 & $9.79^{\mathrm{b}}$ & 8.47 \\
\hline SEM & 0.209 & 0.186 & 0.344 & 0.381 & 1.426 & 1.179 & 0.287 \\
\hline
\end{tabular}

Note: ${ }^{1}=$ Control diet (a. starter diet: $1-6 \mathrm{w}=2910 \mathrm{kcal}$ of ME $/ \mathrm{kg}$ and $19.7 \mathrm{~g}$ of CP $/ \mathrm{kg}$; b. grower diet: $7-12 \mathrm{w}=2854 \mathrm{kcal}$ of ME $/ \mathrm{kg}$ and $17.5 \mathrm{~g}$ of $\mathrm{CP} / \mathrm{kg} ; \mathrm{c}$. developer diet: $13-15 \mathrm{w}=2777 \mathrm{kcal}$ of ME $/ \mathrm{kg}$ and $16.1 \mathrm{~g}$ of $\mathrm{CP} / \mathrm{kg}$; d. pre-laying diet: $16-17 \mathrm{w}=2797 \mathrm{kcal}$ of ME $/ \mathrm{kg}$ and $16.5 \mathrm{~g}$ of CP $/ \mathrm{kg}$; and e. laying diet: $\geq 18 \mathrm{w}=2814 \mathrm{kcal}$ of ME/ $/ \mathrm{kg}$ and $18.4 \mathrm{~g}$ of $\mathrm{CP} / \mathrm{kg}$ ). Self-selection feed= (1) the control feed; (2) HEHP (high energy-high protein diet (3101 $\mathrm{kcal}$ of ME/kg and $23.0 \mathrm{~g}$ of CP/kg); (3) HELP (high energy-low protein diet (3133 kcal of ME/kg and $14.3 \mathrm{~g}$ of CP/ $/ \mathrm{kg}$ ); (4) LEHP (low energy-high protein diet (2638 kcal of ME/kg and $23.4 \mathrm{~g}$ of CP/kg); (5) LELP (low energy-low protein diet (2677 kcal of ME/kg and $14.6 \mathrm{~g}$ of CP/kg).

fed hens at the $3^{\text {rd }}$ week of age, and ME utilization was higher in choice-fed chicks at the $3^{\text {rd }}$ and the $4^{\text {th }}$ weeks of ages and lower at the $6^{\text {th }}$ week of age (Table 3). CP and ME utilizations were influenced by week (Table 2a). CP and ME utilization increased from the $1^{\text {st }}$ week of age until the $6^{\text {th }}$ week of age (Figure 1). There were also interactions between the dietary treatments and the weeks of age on CP and ME utilization (Table 2a). CP and ME utilizations showed that the differences were significantly higher in the last week of age during the starter period (Figure 2).

Grower period. Table $2 b$ presents the probability values of all parameters and Table 4 presents the differences in performance of the pullets every week of age at different dietary treatments. There was an effect of treatments on FI (Table 2b). FI was lower in the choice-fed pullets (Table 4). The feeding method did not affect protein and energy intake (Table $2 b$ ). Feed intake and protein and energy intakes were affected by weeks of age during the grower period (Table $2 \mathrm{~b}$ and 4 ). They were increased at the 9th week of age and remained stable until the end of the grower period (Figure 3). There was no interaction between the dietary treatments and the week of age on feed, protein, and energy intake (Table 2b) during the grower period.

BWG was not affected by treatments $(p>0.05$, Table $2 b)$, but BWG was affected by the weeks of age $(p=0.01$, Table $2 b$ ). BWG increased at the $9^{\text {th }}$ week of age, remained stable until the 11th week of age, and declined significantly at the $12^{\text {th }}$ week of age (Figure 4 ). However, there was no interaction between the dietary treatments and the weeks of age on BWG (Table 2b).

$\mathrm{CP}$ and ME concentrations were affected by the dietary treatment (Table $2 \mathrm{~b}$ ). $\mathrm{CP}$ and ME concentrations were significantly higher in the choice-fed hens than the control-fed pullets (Table 4). CP and ME concentrations were affected by the weeks of age (Table $2 b$ ). CP con- 

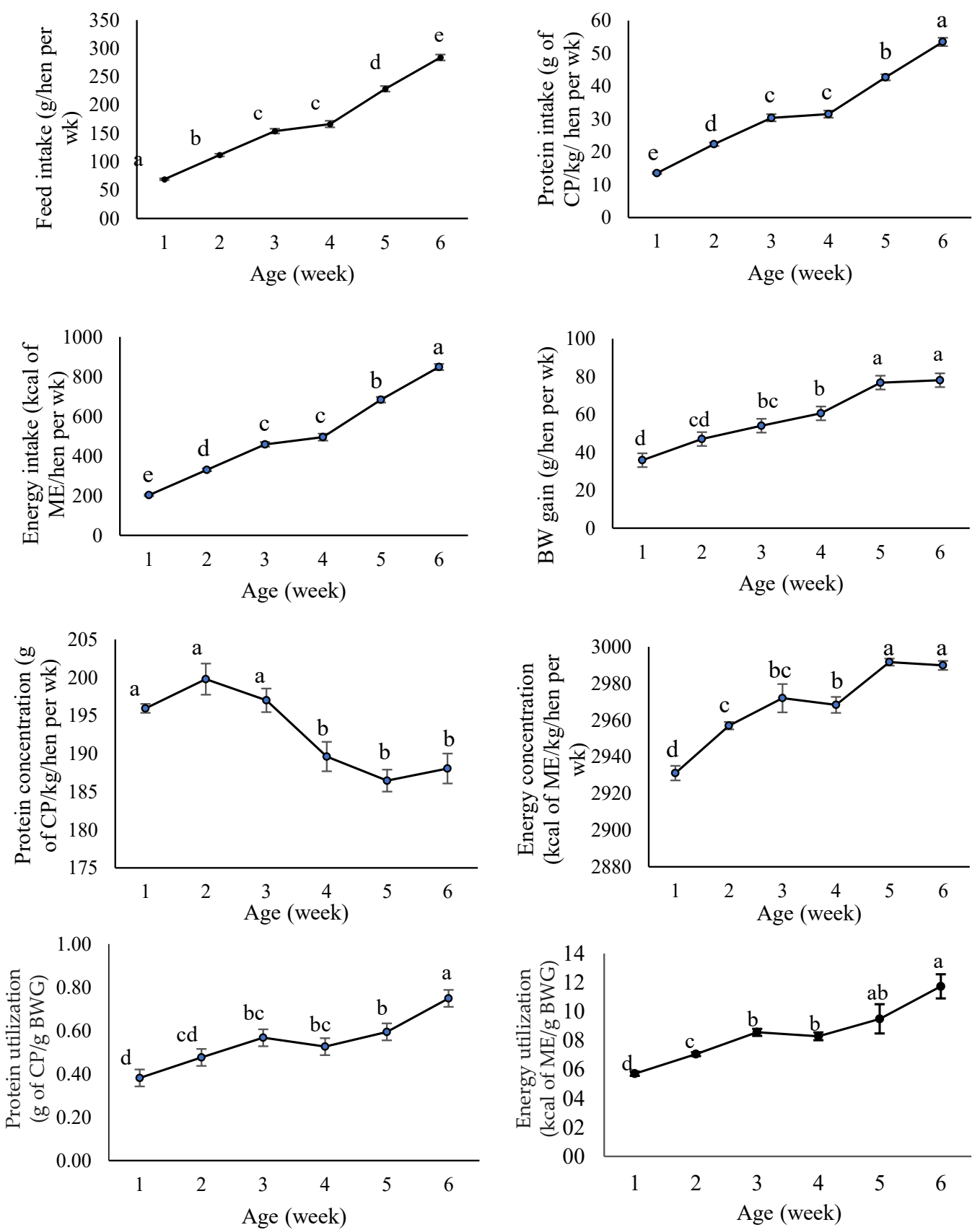

Figure 1. Least square means for traits that show a significant week effect in starter period. Means without a common letter $(a-d)$ differ significantly $(p<0.05)$

centration increased at the $8^{\text {th }}$ week of age and remained stable after the $9^{\text {th }}$ week of age onward (Figure 3). ME concentration increased significantly at the $10^{\text {th }}$ week of age and was not significantly increased until the $12^{\text {th }}$ week (Figure 4). There were interaction effects between the dietary treatments and the weeks of age on the CP and $\mathrm{ME}$ concentrations (Table $2 \mathrm{~b}$ ). Interaction between the dietary treatments and the week of age showed that $\mathrm{CP}$ concentration in the choice-fed pullets was significantly higher from the $8^{\text {th }}$ until the $11^{\text {th }}$ week of age. However, ME concentration was much higher in the choice-fed hens from the beginning of the grower period trial (Figure 4).

$\mathrm{CP}$ and ME utilizations were not influenced by the dietary treatments (Table $2 \mathrm{~b}$ ). CP and ME utilizations were influenced by the week of age (Table $2 b$ ). The lowest $\mathrm{CP}$ and $\mathrm{ME}$ utilizations were found at the $7^{\text {th }}$ week of age and the highest $\mathrm{CP}$ and ME utilization were found at the $12^{\text {th }}$ week of age (Figure 3 ). There were no interactions between the dietary treatments and the weeks of age on CP and ME utilization (Table 2b).

Developer period. Table $2 \mathrm{c}$ presents the probability values of all parameters and Table 5 presents the differences in performance of the pullets every week of age at different dietary treatments. There was an effect of treatment on FI (Table 2c). FI was lower in the choice-fed pullets (Table 5). The feeding method did not affect protein and energy intakes (Table 2c). Feed intake as well as protein and energy intakes were affected by the week of 

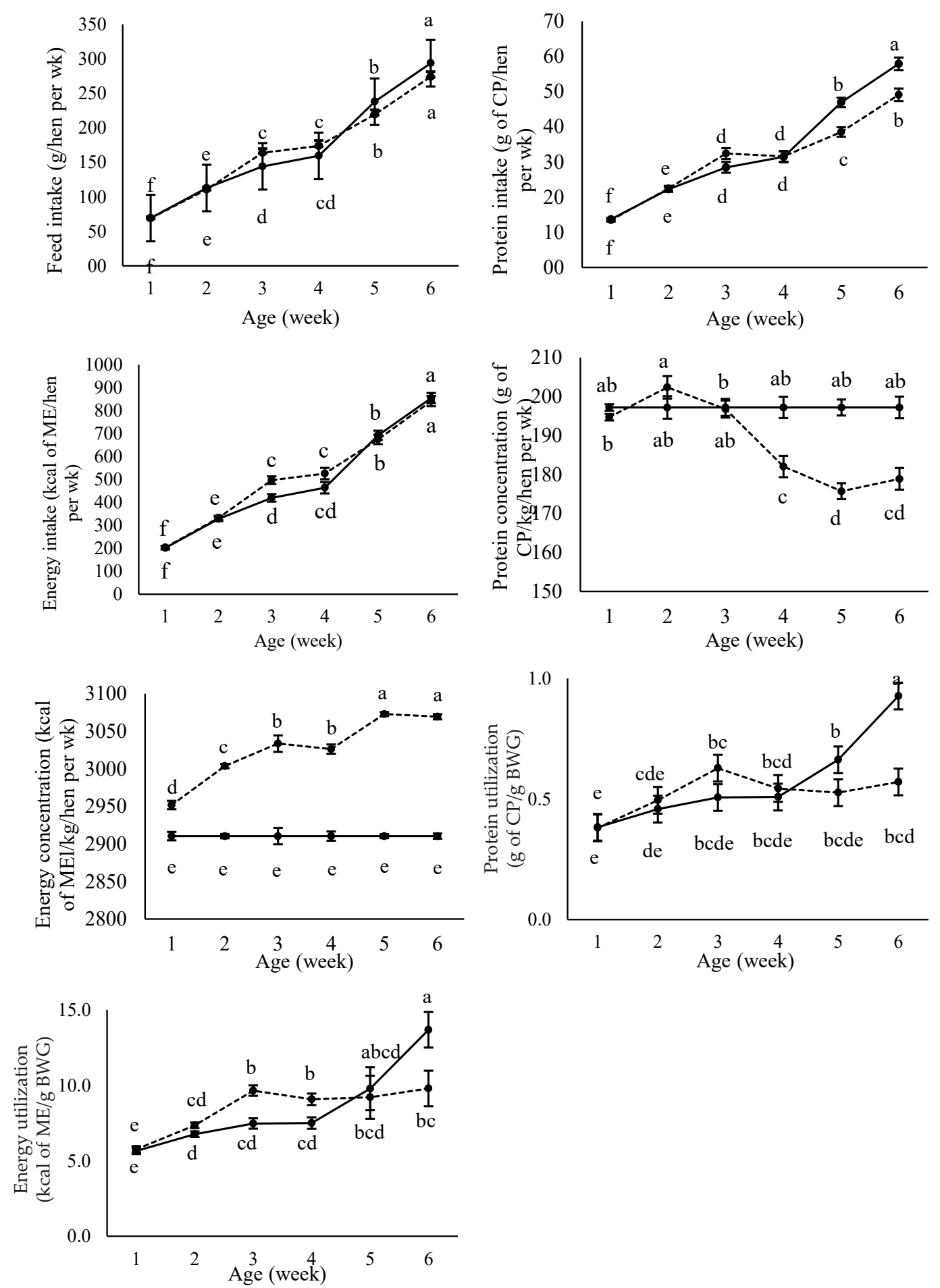

Figure 2. Least square means for traits that show a significant dietary treatments and week interaction in starter period. Means within and between lines without a common letter (a-e) differ significantly $(\mathrm{p}<0.05)$. Control diet (a. starter diet: 0-6 w= $2910 \mathrm{kcal}$ of ME $/ \mathrm{kg}$ and $19.7 \mathrm{~g}$ of $\mathrm{CP} / \mathrm{kg}$; b. grower diet: 7-12 $\mathrm{w}=2854 \mathrm{kcal}$ of ME$/ \mathrm{kg}$ and $17.5 \mathrm{~g}$ of $\mathrm{CP} / \mathrm{kg}$; c. developer diet: 13-15 w= $2777 \mathrm{kcal}$ of $\mathrm{ME} / \mathrm{kg}$ and $16.1 \mathrm{~g}$ of $\mathrm{CP} / \mathrm{kg}$; d. pre-laying diet: 16-17 $\mathrm{w}=2797 \mathrm{kcal}$ of $\mathrm{ME} / \mathrm{kg}$ and $16.5 \mathrm{~g}$ of $\mathrm{CP} / \mathrm{kg}$; and e. laying diet: $\geq 18 \mathrm{w}=2814 \mathrm{kcal}$ of $\mathrm{ME} / \mathrm{kg}$ and $18.4 \mathrm{~g}$ of CP/ $\mathrm{kg}$ ). Choice diet $=(1)$ the control diet, (2) HEHP (high energy- high protein diet (3101 kcal of ME/kg and 23.0 $\mathrm{g}$ of $\mathrm{CP} / \mathrm{kg}$ ), (3) HELP (high energy-low protein diet (3133 kcal of ME/kg and $14.3 \mathrm{~g}$ of CP/kg), (4) LEHP (low energy-high protein diet (2638 kcal of ME/ $\mathrm{kg}$ and $23.4 \mathrm{~g}$ of $\mathrm{CP} / \mathrm{kg}$ ), or (5) LELP (low energy-low protein diet (2677 kcal of ME/kg and $14.6 \mathrm{~g}$ of CP/kg). Control (-•-); Self-selection (---•---).

age (Table $2 \mathrm{c}$ and 7 ) and were increased at the 15 th week of age (Figure 5). There was an interaction between the dietary treatments and week of age on feed and energy intakes (Table 2c). Interaction between the dietary treat- ments and the week of age showed that the differences were significantly higher in week 15 of age for feed and energy intakes (Figure 6). 
Table 4. Least squares mean of performance variables in local female chickens from 7 to 12 week of age as affected by dietary treatment ${ }^{1}$

\begin{tabular}{|c|c|c|c|c|c|c|c|}
\hline \multirow{2}{*}{ Variables } & \multicolumn{7}{|c|}{ Week } \\
\hline & 7 & 8 & 9 & 10 & 11 & 12 & Average \\
\hline \multicolumn{8}{|c|}{ Feed intake (g/bird/week) } \\
\hline Control & 337.1 & $331.2^{\mathrm{a}}$ & 390.9 & 389.2 & $429.1^{\mathrm{a}}$ & 411.5 & $381.5^{\mathrm{a}}$ \\
\hline Self-Selection & 312.8 & $289.5^{\mathrm{b}}$ & 371.8 & 398.4 & $363.4^{\mathrm{b}}$ & 406.7 & $357.1^{\mathrm{b}}$ \\
\hline SEM & 15.09 & 15.09 & 15.09 & 15.09 & 15.09 & 15.09 & 6.16 \\
\hline \multicolumn{8}{|c|}{ Protein intake (g of $\mathrm{CP} / \mathrm{bird} /$ week) } \\
\hline Control & 58.8 & 57.8 & 68.2 & 67.9 & 74.9 & 71.8 & 66.6 \\
\hline Self-Selection & 55.6 & 54.2 & 67.7 & 74.6 & 67.9 & 73.3 & 65.6 \\
\hline SEM & 2.65 & 2.65 & 2.65 & 2.65 & 2.65 & 2.65 & 1.08 \\
\hline \multicolumn{8}{|c|}{ Energy intake (kcal of ME/kg/bird/week) } \\
\hline Control & 961.9 & 945.1 & 1115.4 & 1110.7 & 1224.3 & 1174.2 & 1088.6 \\
\hline Self-Selection & 959.6 & 889.9 & 1143.1 & 1229.5 & 1121.5 & 1258.3 & 1100.3 \\
\hline SEM & 44.98 & 44.98 & 44.98 & 44.98 & 44.98 & 44.98 & 18.36 \\
\hline \multicolumn{8}{|l|}{ BWG (g/bird/week) } \\
\hline Control & 89.5 & 76.9 & 99.7 & 84.2 & $88.6^{\mathrm{a}}$ & $65.2^{\mathrm{a}}$ & 84.0 \\
\hline Self-Selection & 75.0 & 81.1 & 91.3 & 108.4 & $76.9^{\mathrm{b}}$ & $79.1^{\mathrm{b}}$ & 85.3 \\
\hline SEM & 7.25 & 10.31 & 13.56 & 13.66 & 3.09 & 4.05 & 2.01 \\
\hline \multicolumn{8}{|c|}{ Protein concentration ( $\mathrm{g}$ of $\mathrm{CP} / \mathrm{kg}$ ) } \\
\hline Control & 174.5 & $174.5^{\mathrm{a}}$ & $174.5^{\mathrm{a}}$ & $174.5^{\mathrm{a}}$ & $174.5^{\mathrm{a}}$ & 174.5 & $174.5^{\mathrm{a}}$ \\
\hline Self-Selection & 178.1 & $187.9^{b}$ & $182.6^{\mathrm{b}}$ & $187.3^{\mathrm{b}}$ & $187.4^{\mathrm{b}}$ & 180.0 & $183.9^{\mathrm{b}}$ \\
\hline SEM & 1.93 & 1.21 & 1.47 & 1.48 & 2.90 & 2.50 & 1.04 \\
\hline \multicolumn{8}{|c|}{ Energy concentration (kcal of ME/kg) } \\
\hline Control & $2853.5^{\mathrm{a}}$ & $2853.5^{a}$ & $2853.5^{a}$ & $2853.5^{\mathrm{a}}$ & $2853.5^{a}$ & $2853.5^{\mathrm{a}}$ & $2853.5^{\mathrm{a}}$ \\
\hline Self-Selection & $3067.5^{\mathrm{b}}$ & $3073.0^{\mathrm{b}}$ & $3078.3^{\mathrm{b}}$ & $3086.1^{\mathrm{b}}$ & $3085.1^{\mathrm{b}}$ & $3094.2^{\mathrm{b}}$ & $3080.7^{b}$ \\
\hline SEM & 3.38 & 2.98 & 8.56 & 2.68 & 2.66 & 2.8 & 1.96 \\
\hline \multicolumn{8}{|c|}{ Utilization of $\mathrm{CP}$ ( $\mathrm{g}$ of $\mathrm{CP} / \mathrm{g}$ BWG) } \\
\hline Control & 0.66 & 0.87 & 0.80 & 1.07 & 0.85 & $1.12^{\mathrm{a}}$ & 0.89 \\
\hline Self-Selection & 0.83 & 0.72 & 0.82 & 0.72 & 0.89 & $0.93^{\mathrm{b}}$ & 0.82 \\
\hline SEM & 0.09 & 0.16 & 0.15 & 0.23 & 0.04 & 0.05 & 0.05 \\
\hline \multicolumn{8}{|c|}{ Utilization of energy (kcal of ME/g BWG) } \\
\hline Control & 10.78 & 14.22 & 13.01 & 17.44 & 13.86 & 18.29 & 14.60 \\
\hline Self-Selection & 14.27 & 11.82 & 13.90 & 11.90 & 14.74 & 16.09 & 13.79 \\
\hline SEM & 1.663 & 2.639 & 2.501 & 3.820 & 0.715 & 0.91 & 0.755 \\
\hline
\end{tabular}

Note: ${ }^{1}=$ Control diet (a. starter diet: $1-6 \mathrm{w}=2910 \mathrm{kcal}$ of ME $/ \mathrm{kg}$ and $19.7 \mathrm{~g}$ of CP $/ \mathrm{kg}$; b. grower diet: 7-12 w= 2854 kcal of ME/kg and $17.5 \mathrm{~g}$ of CP/kg; . developer diet: $13-15 \mathrm{w}=2777 \mathrm{kcal}$ of $\mathrm{ME} / \mathrm{kg}$ and $16.1 \mathrm{~g}$ of $\mathrm{CP} / \mathrm{kg}$; d. pre-laying diet: $16-17 \mathrm{w}=2797 \mathrm{kcal}$ of $\mathrm{ME} / \mathrm{kg}$ and $16.5 \mathrm{~g}$ of $\mathrm{CP} / \mathrm{kg}$; and e. laying diet: $\geq 18 \mathrm{w}=2814 \mathrm{kcal}$ of $\mathrm{ME} / \mathrm{kg}$ and $18.4 \mathrm{~g}$ of CP/kg). Self-selection feed= (1) the control feed; (2) HEHP (high energy-high protein diet (3101 $\mathrm{kcal}$ of ME/kg and $23.0 \mathrm{~g}$ of CP/kg); (3) HELP (high energy-low protein diet (3133 kcal of ME/kg and 14.3 g of CP/kg); (4) LEHP (low energy-high protein diet (2638 kcal of ME/kg and $23.4 \mathrm{~g}$ of $\mathrm{CP} / \mathrm{kg}$ ); (5) LELP (low energy-low protein diet (2677 kcal of ME/kg and $14.6 \mathrm{~g}$ of CP/kg).

BWG was affected by the feeding method ( $\mathrm{p}=0.035$, Table 2c), and BWG was higher in the choice-fed pullets $(\mathrm{p}<0.035 ;$ Table 5$)$. BWG was affected by the week of age $(\mathrm{p}=0.006$, Table $2 \mathrm{c})$. BWG increased at the 14 th week of age and decreased at the $15^{\text {th }}$ week (Figure 6). However, there was no interaction between the dietary treatments and the week of age on BWG (Table 2c).

$\mathrm{CP}$ and $\mathrm{ME}$ concentrations were affected by the dietary treatments (Table 2c). CP and ME concentrations were significantly higher in the choice-fed pullets than the control-fed pullets (Table 5). There was no significant effect of a week of age, and there was no interaction effect between the dietary treatment and the week of age on $\mathrm{CP}$ and ME concentrations (Table 2c).

$\mathrm{CP}$ and ME utilizations were not influenced by the dietary treatments (Table 2c and 7). CP and ME utilizations were influenced by the week of age (Table 2c). CP and ME utilizations declined at the $14^{\text {th }}$ week of age and increased at the $15^{\text {th }}$ week of age (Figure 6). There was no interaction between dietary treatments and the week of age on CP and ME utilization (Table 2c and 5).

Pre-laying period. Table $2 \mathrm{~d}$ presents the probability values of all parameters, and Table 6 shows the differences in performance of the pullets every week of age at different dietary treatments.

There was an effect of treatment on FI ( $p=0.017$; Table 2d). FI was lower in the choice-fed pullets (Table 6). The feeding method did not affect protein and energy intakes (Table 2d). Feed intake, as well as protein and energy intakes were affected by the weeks of age (Table $2 \mathrm{~d}$ and 6) and were increased at the $18^{\text {th }}$ week of age onward (Figure 7). There was an interaction between the dietary treatment and the week of ages on feed, protein, and energy intakes (Table 2d). Interaction between the dietary treatment and the week of age showed that the 

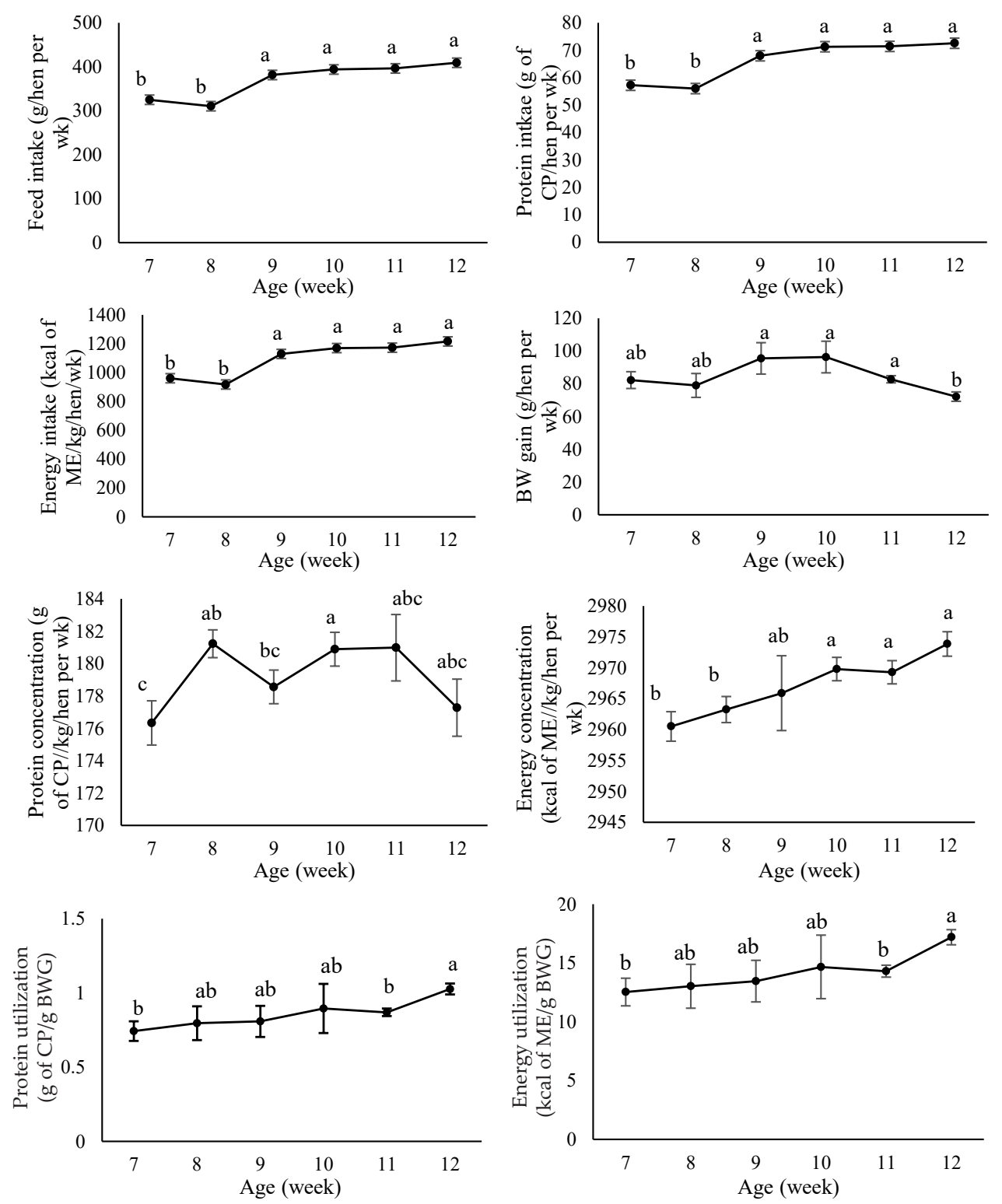

Figure 3. Least square means for traits that show a significant week effect in grower period. Means without a common letter $(a-c)$ differ significantly $(\mathrm{p}<0.05)$.
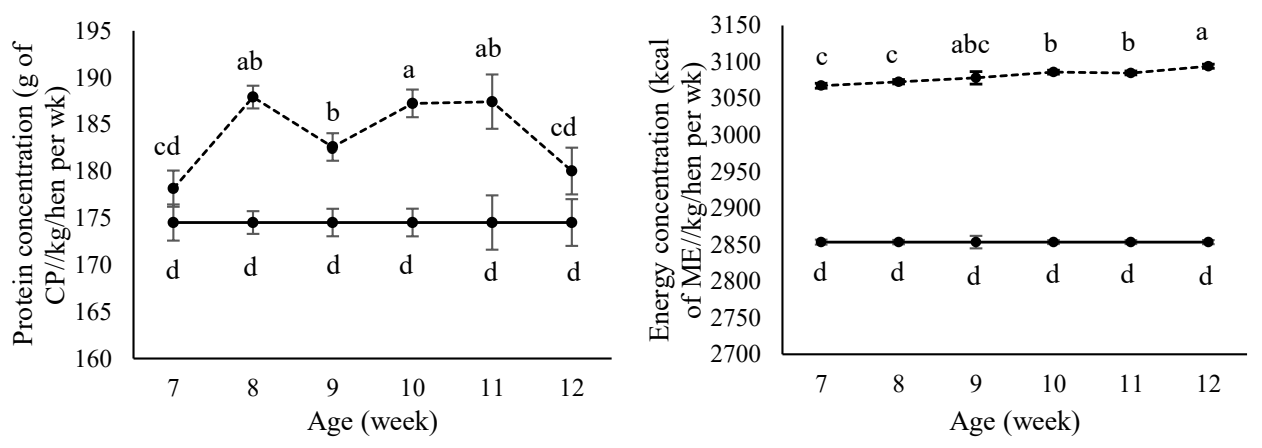

Figure 4. Least square means for traits that show a significant dietary treatments and week interaction in grower period. Means within and between lines without a common letter $(\mathrm{a}-\mathrm{d})$ differ significantly $(\mathrm{p}<0.05)$. Control diet (a. starter diet: 0-6 w= $2910 \mathrm{kcal}$ of ME $/ \mathrm{kg}$ and $19.7 \mathrm{~g}$ of CP $/ \mathrm{kg}$; b. grower diet: $7-12 \mathrm{w}=2854 \mathrm{kcal}$ of ME $/ \mathrm{kg}$ and $17.5 \mathrm{~g}$ of $\mathrm{CP} / \mathrm{kg}$; c. developer diet: $13-15 \mathrm{w}=2777 \mathrm{kcal}$ of $\mathrm{ME} / \mathrm{kg}$ and $16.1 \mathrm{~g}$ of $\mathrm{CP} / \mathrm{kg}$; d. pre-laying diet: 16-17 $\mathrm{w}=2797 \mathrm{kcal}$ of $\mathrm{ME} / \mathrm{kg}$ and $16.5 \mathrm{~g}$ of $\mathrm{CP} / \mathrm{kg}$; and e. laying diet: $\geq 18 \mathrm{w}=2814 \mathrm{kcal}$ of ME$/ \mathrm{kg}$ and $18.4 \mathrm{~g}$ of CP/ $\mathrm{kg}$ ). Choice diet = (1) the control diet, (2) HEHP (high energy- high protein diet (3101 kcal of ME/kg and 23.0 $\mathrm{g}$ of $\mathrm{CP} / \mathrm{kg}$ ), (3) HELP (high energy-low protein diet (3133 kcal of ME/kg and $14.3 \mathrm{~g}$ of CP/kg), (4) LEHP (low energy-high protein diet (2638 kcal of ME/ $\mathrm{kg}$ and $23.4 \mathrm{~g}$ of $\mathrm{CP} / \mathrm{kg}$ ), or (5) LELP (low energy-low protein diet (2677 kcal of ME/kg and $14.6 \mathrm{~g}$ of CP/kg). Control (-・-); Self-selection (---•---). 
Table 5. Least squares mean of performance variables in local female chickens from 13 to 15 week of age as affected by dietary treatment ${ }^{1}$

\begin{tabular}{|c|c|c|c|c|}
\hline \multirow{2}{*}{ Variables } & \multicolumn{4}{|c|}{ Week } \\
\hline & 13 & 14 & 15 & Average \\
\hline \multicolumn{5}{|c|}{ Feed intake (g/bird/week) } \\
\hline Control & $468.4^{\mathrm{a}}$ & 428.3 & $552.3^{\mathrm{a}}$ & $483.0^{\mathrm{a}}$ \\
\hline Self-Selection & $406.5^{\mathrm{b}}$ & 408.2 & $415.2^{\mathrm{b}}$ & $410.0^{\mathrm{b}}$ \\
\hline SEM & 10.46 & 23.29 & 12.68 & 9.89 \\
\hline \multicolumn{5}{|c|}{ Protein intake (g of $\mathrm{CP} /$ bird/week) } \\
\hline Control & 75.5 & 69 & $89.0^{\mathrm{a}}$ & 77.8 \\
\hline Self-Selection & 74.3 & 74.7 & $78.6^{\mathrm{b}}$ & 75.9 \\
\hline SEM & 2.02 & 4.49 & 2.31 & 1.8 \\
\hline \multicolumn{5}{|c|}{ Energy intake (kcal of ME/kg/bird/week) } \\
\hline Control & 1300.6 & 1189.4 & $1533.8^{\mathrm{a}}$ & 1341.3 \\
\hline Self-Selection & 1258.3 & 1260.5 & $1282.4^{\mathrm{b}}$ & 1267.1 \\
\hline SEM & 29.7 & 68.61 & 35.54 & 28.74 \\
\hline \multicolumn{5}{|c|}{ BWG (g/bird/week) } \\
\hline Control & 60.9 & 75.2 & 38.6 & $58.2^{\mathrm{a}}$ \\
\hline Self-Selection & 64.8 & 77.1 & 50.2 & $64.0^{\mathrm{b}}$ \\
\hline SEM & 2.55 & 6.11 & 5.47 & 1.74 \\
\hline \multicolumn{5}{|c|}{ Protein concentration $(\mathrm{g} / \mathrm{kg})$} \\
\hline Control & $161.1^{\mathrm{a}}$ & $161.1^{\mathrm{a}}$ & $161.1^{\mathrm{a}}$ & $161.1^{\mathrm{a}}$ \\
\hline Self-Selection & $182.8^{\mathrm{b}}$ & $182.5^{\mathrm{b}}$ & $189.2^{\mathrm{b}}$ & $184.8^{\mathrm{b}}$ \\
\hline SEM & 2.76 & 3.03 & 1.29 & 1.05 \\
\hline \multicolumn{5}{|c|}{ Energy concentration (kcal of ME/kg) } \\
\hline Control & $2776.9^{a}$ & $2776.9^{\mathrm{a}}$ & $2776.9^{\mathrm{a}}$ & $2776.9^{a}$ \\
\hline Self-Selection & $3095.7^{\mathrm{b}}$ & $3088.8^{\mathrm{b}}$ & $3088.6^{\mathrm{b}}$ & $3091.0^{\mathrm{b}}$ \\
\hline SEM & 3.01 & 3.01 & 3.01 & 1.74 \\
\hline \multicolumn{5}{|c|}{ Utilization of $\mathrm{CP}$ ( $\mathrm{g}$ of $\mathrm{CP} / \mathrm{g}$ BWG) } \\
\hline Control & 1.24 & 0.94 & 2.9 & 1.69 \\
\hline Self-Selection & 1.16 & 0.99 & 1.63 & 1.26 \\
\hline SEM & 0.06 & 0.07 & 0.59 & 0.2 \\
\hline \multicolumn{5}{|c|}{ Utilization of energy (kcal of ME/g BWG) } \\
\hline Control & 21.41 & 16.17 & 49.97 & 29.18 \\
\hline Self-Selection & 19.7 & 16.61 & 26.57 & 20.96 \\
\hline SEM & 1.024 & 0.987 & 10.022 & 3.249 \\
\hline
\end{tabular}

Note: ${ }^{1}=$ Control diet $($ a. starter diet: $1-6 \mathrm{w}=2910 \mathrm{kcal}$ of ME $/ \mathrm{kg}$ and $19.7 \mathrm{~g}$ of $\mathrm{CP} / \mathrm{kg}$; b. grower diet: $7-12 \mathrm{w}=2854 \mathrm{kcal}$ of $\mathrm{ME} / \mathrm{kg}$ and $17.5 \mathrm{~g}$ of $\mathrm{CP} / \mathrm{kg}$; c. developer diet: $13-15 \mathrm{w}=2777 \mathrm{kcal}$ of $\mathrm{ME} / \mathrm{kg}$ and $16.1 \mathrm{~g}$ of $\mathrm{CP} / \mathrm{kg}$; d. pre-laying diet: $16-17 \mathrm{w}=2797 \mathrm{kcal}$ of $\mathrm{ME} / \mathrm{kg}$ and $16.5 \mathrm{~g}$ of $\mathrm{CP} / \mathrm{kg}$; and e. laying diet: $\geq 18 \mathrm{w}=2814 \mathrm{kcal}$ of ME $/ \mathrm{kg}$ and $18.4 \mathrm{~g}$ of $\mathrm{CP} / \mathrm{kg}$ ). Self-selection feed= (1) the control feed; (2) HEHP (high energy-high protein diet ( $3101 \mathrm{kcal}$ of $\mathrm{ME} / \mathrm{kg}$ and $23.0 \mathrm{~g}$ of $\mathrm{CP} / \mathrm{kg}$ ); (3) HELP (high energy-low protein diet (3133 kcal of ME/kg and $14.3 \mathrm{~g}$ of $\mathrm{CP} / \mathrm{kg}$ ); (4) LEHP (low energy-high protein diet $(2638 \mathrm{kcal}$ of $\mathrm{ME} / \mathrm{kg}$ and $23.4 \mathrm{~g}$ of $\mathrm{CP} / \mathrm{kg}$ ); (5) LELP (low energy-low protein $\operatorname{diet}(2677 \mathrm{kcal}$ of $\mathrm{ME} / \mathrm{kg}$ and $14.6 \mathrm{~g}$ of $\mathrm{CP} / \mathrm{kg})$.

differences were significantly higher in the last week of age (Figure 8).

BWG was significantly affected by the dietary treatments ( $p=0.023$, Table $2 d$ ) and BWG was higher in the choice-fed pullets (Table 6). BWG was affected by the week of age $(p<0.001$, Table $2 d)$. BWG decreased from the $16^{\text {th }}$ to the $18^{\text {th }}$ week of age and increased again until the $20^{\text {th }}$. After that, BWG decreased significantly until the $22^{\text {nd }}$ week of age (Figure 7 ). There was an interaction effect between the dietary treatment and the week of age on BWG (Table $2 \mathrm{~d}$ ).
$\mathrm{CP}$ and ME concentrations were affected by the dietary treatments (Table $2 \mathrm{~d}$ ). $\mathrm{CP}$ and ME concentrations were significantly higher in the choice-fed pullets than the control-fed pullets (Table 6). CP and ME concentrations were affected by the week of age (Table $2 \mathrm{~d}$ ). CP concentration increased at the $18^{\text {th }}$ week of age and remained stable until the $22^{\text {nd }}$ week (Figure 7 ). ME concentration increased significantly after the $17^{\text {th }}$ week of age onward (Figure 7). There were interaction effects between the dietary treatments and the week of age on $\mathrm{CP}$ and $\mathrm{ME}$ concentrations (Table $2 \mathrm{~d}$ ). Interaction between the dietary treatments and week of age showed that $\mathrm{CP}$ concentration in the choice-fed pullets was significantly higher than the $16^{\text {th }}$ until the $21^{\text {st }}$. However, ME concentration was much higher in the choice-fed pullets from the beginning of the pre-laying period trial (Figure 4).

$\mathrm{CP}$ and ME utilizations were not influenced by the dietary treatments (Table $2 \mathrm{~d}$ and 6). CP and ME utilizations were affected by the week of age (Table $2 \mathrm{~d}$ ). CP and ME utilization increased from the 16th to the 18th weeks of age and decreased until the 20th. After that, they increased until the $22^{\text {nd }}$ week of age with the same level as at the $18^{\text {th }}$ week (Figure 7 ). There was no interaction between the dietary treatments and the week of age on CP and ME utilization (Table $2 \mathrm{~d}$ and 6).

The correlations between energy and CP levels with BWG are presented in Table 7. ME level of control dietary treatment has a negative correlation with BWG during a starter $(-0.231)$ and a grower $(-0.777)$ periods and a positive correlation during developer (0.922) and pre-laying (0.658) periods. On the other hand, all the ME level of the choice dietary treatment has a positive correlation with BWG during all ages (0.083 to 0.909). CP level of control dietary treatment has a negative correlation with BWG during the starter period $(0.624)$ and a positive correlation during the grower (0.362), developer (0.922), and pre-laying (0.658) periods. While CP level of the choice dietary treatment has a negative correlation with BWG during the starter (-0.819) and developer $(-0.908)$ periods and a positive correlation during the grower (0.396) and pre-laying (0.325) periods.

\section{DISCUSSION}

The cyclical temperature and relative humidity in the barn during the experiment depended on the environmental climate conditions. When the temperature in the barn rises, the relative humidity falls and vice versa. Dropping in relative humidity at the time of high temperature could help the bird release the heat load by evaporation to the environment, especially during the hot period that generally happens between 12:00 to $17: 00 \mathrm{~h}$. We observed that the birds were changing their behavior and panting when the temperature raised above $28^{\circ} \mathrm{C}$, and it depicted that the temperature was above the normal range for them. Therefore, the environmental temperature conditions indicate that the birds experience heat stress during the time of hot period of the day because changing the behavior and panting are indicators of heat stress (Sugiharto et al., 2017; Wang et al., 2018) and the birds spent more time for panting and drinking and less time for walking and 

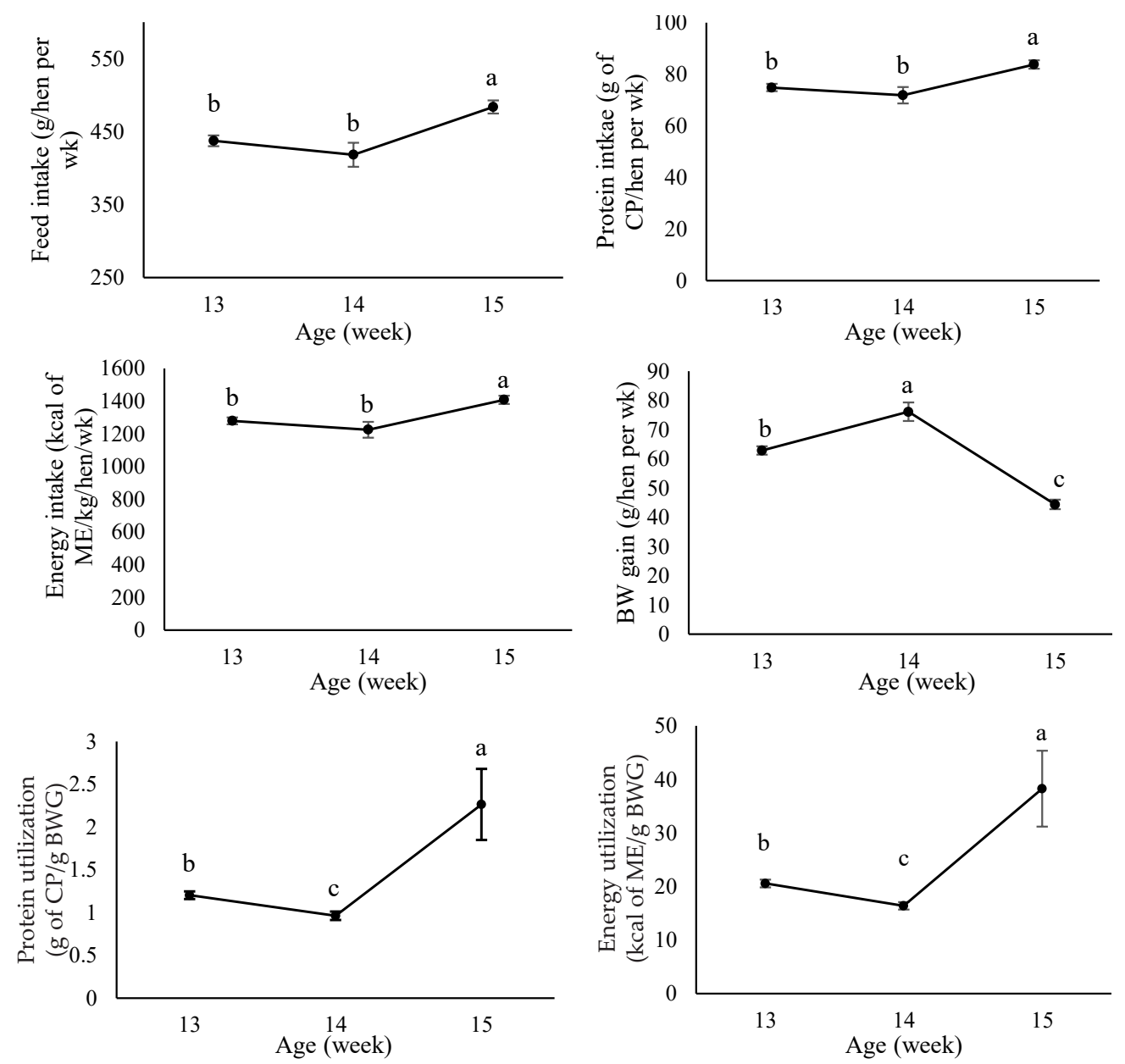

Figure 5. Least square means for traits that show a significant week effect in developer period. Means without a common letter $(\mathrm{a}-\mathrm{c})$ differ significantly $(\mathrm{p}<0.05)$.
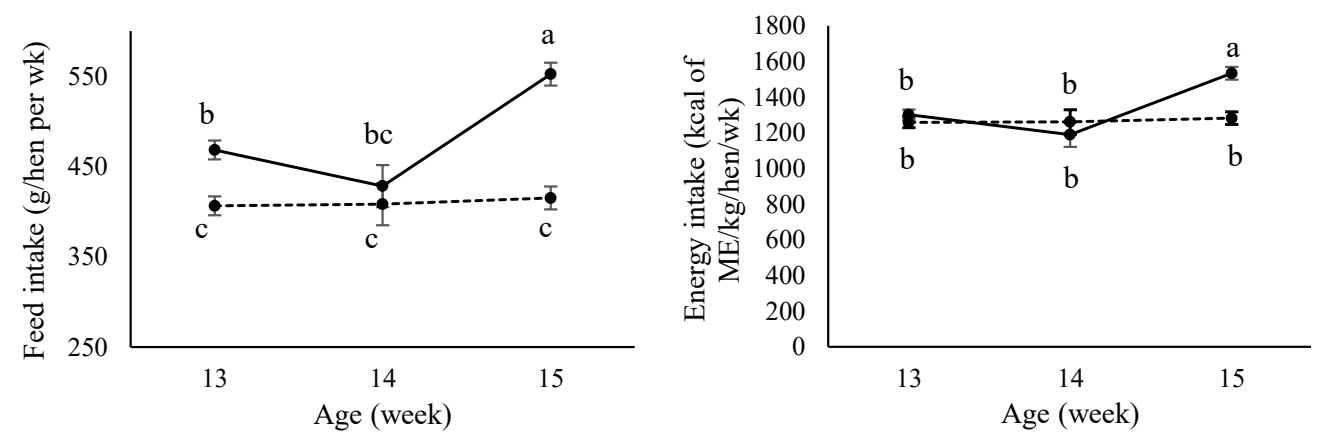

Figure 6. Least square means for traits that show a significant dietary treatments and week interaction in developer period. Means within and between lines without a common letter $(\mathrm{a}-\mathrm{c})$ differ significantly $(\mathrm{p}<0.05)$. Control diet (a. starter diet: 0-6 w= $2910 \mathrm{kcal}$ of ME $/ \mathrm{kg}$ and $19.7 \mathrm{~g}$ of CP $/ \mathrm{kg}$; b. grower diet: 7-12 $\mathrm{w}=2854 \mathrm{kcal}$ of ME/ $\mathrm{kg}$ and $17.5 \mathrm{~g}$ of $\mathrm{CP} / \mathrm{kg}$; c. developer diet: $13-15 \mathrm{w}=2777 \mathrm{kcal}$ of $\mathrm{ME} / \mathrm{kg}$ and $16.1 \mathrm{~g}$ of CP $/ \mathrm{kg}$; d. pre-laying diet: $16-17 \mathrm{w}=2797 \mathrm{kcal}$ of $\mathrm{ME} / \mathrm{kg}$ and $16.5 \mathrm{~g}$ of $\mathrm{CP} / \mathrm{kg}$; and e. laying diet: $\geq 18 \mathrm{w}=2814 \mathrm{kcal}$ of ME$/ \mathrm{kg}$ and $18.4 \mathrm{~g}$ of $\mathrm{CP} / \mathrm{kg}$ ). Choice diet= (1) the control diet, (2) HEHP (high energy- high protein diet $(3101 \mathrm{kcal}$ of ME/kg and $23.0 \mathrm{~g}$ of CP/kg), (3) HELP (high energy-low protein diet (3133 kcal of ME $/ \mathrm{kg}$ and $14.3 \mathrm{~g}$ of CP/ $\mathrm{kg}$ ), (4) LEHP (low energy-high protein diet (2638 kcal of ME/kg and $23.4 \mathrm{~g}$ of CP/kg), or (5) LELP (low energy-low protein diet (2677 kcal of ME/kg and $14.6 \mathrm{~g}$ of CP/kg). Control (-•-); Self-selection (---•---).

feeding (He et al., 2018). High ambient temperature has a negative effect on body weight and feed intake of laying hens (He et al., 2018) and broilers (Syafwan et al., 2011, 2012; Wang et al., 2018).
The choice-fed hens in the present study consumed a much lower amount of feed than the control-fed hens during the grower until pre-laying periods, and overall they consumed feed $7 \%$ lower than the control-fed hens. The lower feed intake in the choice-fed hens was related 
Table 6. Least squares mean of performance variables in local female chickens from 16 to 22 week of age as affected by dietary treatment $^{1}$

\begin{tabular}{|c|c|c|c|c|c|c|c|c|}
\hline \multirow{2}{*}{ Variables } & \multicolumn{8}{|c|}{ Week } \\
\hline & 16 & 17 & 18 & 19 & 20 & 21 & 22 & Average \\
\hline \multicolumn{9}{|c|}{ Feed intake (g/bird/week) } \\
\hline Control & $504.6^{\mathrm{a}}$ & 414.5 & $514.9^{\mathrm{a}}$ & 537.4 & $587.0^{\mathrm{a}}$ & 558.5 & $580.6^{a}$ & $528.2^{\mathrm{a}}$ \\
\hline Self-Selection & $417.4^{\mathrm{b}}$ & 364.8 & $414.2^{\mathrm{b}}$ & 539.7 & $520.6^{\mathrm{b}}$ & 563.7 & $656.3^{\mathrm{b}}$ & $496.6^{\mathrm{b}}$ \\
\hline SEM & 10.88 & 18.63 & 23.27 & 46.97 & 9.67 & 18.95 & 18.71 & 8.58 \\
\hline \multicolumn{9}{|c|}{ Protein intake (g of $\mathrm{CP} /$ hen/week) } \\
\hline Control & 83.2 & 68.3 & $94.7^{\mathrm{a}}$ & 98.8 & $107.9^{a}$ & 102.7 & $106.7^{a}$ & 94.6 \\
\hline Self-Selection & 77.5 & 68.7 & $78.0^{\mathrm{b}}$ & 103.4 & $97.2^{\mathrm{b}}$ & 107.5 & $122.9^{\mathrm{b}}$ & 93.6 \\
\hline SEM & 2.06 & 2.93 & 4.31 & 8.97 & 1.63 & 3.40 & 3.32 & 1.52 \\
\hline \multicolumn{9}{|c|}{ Energy intake (kcal of ME/kg/bird/week) } \\
\hline Control & $1411.2^{\mathrm{a}}$ & 1159.2 & $1449.1^{\mathrm{a}}$ & 1512.2 & 1652 & 1571.7 & $1527.9^{a}$ & 1484.1 \\
\hline Self-Selection & $1290.5^{\mathrm{b}}$ & 1102.9 & $1267.9^{b}$ & 1663.1 & 1602.2 & 1734.4 & $2034.4^{\mathrm{b}}$ & 1527.9 \\
\hline SEM & 33.71 & 52.31 & 65.99 & 147.31 & 29.65 & 56.26 & 26.16 & 26.15 \\
\hline \multicolumn{9}{|c|}{ BWG (g/bird/week) } \\
\hline Control & $37.7^{\mathrm{a}}$ & 33.2 & 33.6 & 66.5 & 74.4 & $57.7^{\mathrm{a}}$ & 57.6 & $51.34^{\mathrm{a}}$ \\
\hline Self-Selection & $52.2^{\mathrm{b}}$ & 31.9 & 37.1 & 74.5 & 82.5 & $79.0^{\mathrm{b}}$ & 46.1 & $57.59^{\mathrm{b}}$ \\
\hline SEM & 5.05 & 5.05 & 5.05 & 5.05 & 5.05 & 5.05 & 5.05 & 1.90 \\
\hline \multicolumn{9}{|c|}{ Protein concentration ( $\mathrm{g}$ of $\mathrm{CP} / \mathrm{kg}$ ) } \\
\hline Control & $164.9^{\mathrm{a}}$ & $164.9^{\mathrm{a}}$ & 183.9 & $183.9^{a}$ & $183.9^{a}$ & $183.9^{\mathrm{a}}$ & 183.9 & $178.4^{\mathrm{a}}$ \\
\hline Self-Selection & $185.6^{\mathrm{b}}$ & $188.8^{\mathrm{b}}$ & 188.3 & $191.6^{\mathrm{b}}$ & $186.9^{\mathrm{b}}$ & $190.9^{b}$ & 187.4 & $188.5^{\mathrm{b}}$ \\
\hline SEM & 1.12 & 2.37 & 1.78 & 1.28 & 0.95 & 1.05 & 1.21 & 0.55 \\
\hline \multicolumn{9}{|c|}{ Energy concentration (kcal of ME/kg) } \\
\hline Control & $2796.8^{a}$ & $2796.8^{\mathrm{a}}$ & $2814.1^{\mathrm{a}}$ & $2814.1^{\mathrm{a}}$ & $2814.1^{\mathrm{a}}$ & $2814.1^{\mathrm{a}}$ & $2814.1^{\mathrm{a}}$ & $2809.1^{\mathrm{a}}$ \\
\hline Self-Selection & $3091.5^{\mathrm{b}}$ & $3023.6^{b}$ & $3061.4^{b}$ & $3078.7^{b}$ & $3077.8^{b}$ & $3077.4^{\mathrm{b}}$ & $3098.7^{b}$ & $3072.7^{b}$ \\
\hline SEM & 4.19 & 5.59 & 3.92 & 4.61 & 4.26 & 3.49 & 4.06 & 2.31 \\
\hline \multicolumn{9}{|c|}{ Utilization of $\mathrm{CP}$ ( $\mathrm{g}$ of $\mathrm{CP} / \mathrm{g}$ BWG) } \\
\hline Control & $2.36^{\mathrm{a}}$ & 2.24 & 2.96 & 1.53 & $1.46^{\mathrm{a}}$ & $1.85^{\mathrm{a}}$ & 2.14 & 1.85 \\
\hline Self-Selection & $1.56^{\mathrm{b}}$ & 2.35 & 2.19 & 1.41 & $1.19^{\mathrm{b}}$ & $1.38^{\mathrm{b}}$ & 2.84 & 1.96 \\
\hline SEM & 0.19 & 0.33 & 0.3 & 0.14 & 0.05 & 0.14 & 0.10 & 0.10 \\
\hline \multicolumn{9}{|c|}{ Utilization of energy (kcal of ME/g BWG) } \\
\hline Control & $40.04^{\mathrm{a}}$ & 37.92 & 45.31 & 23.43 & 22.33 & 28.32 & 32.75 & 30.20 \\
\hline Self-Selection & $26.06^{\mathrm{b}}$ & 37.90 & 35.72 & 22.80 & 19.66 & 22.28 & 46.97 & 33.05 \\
\hline SEM & 3.271 & 5.501 & 4.765 & 2.381 & 0.869 & 2.197 & 4.947 & 1.62 \\
\hline
\end{tabular}

Note: ${ }^{1}=$ Control diet (a. starter diet: $1-6 \mathrm{w}=2910 \mathrm{kcal}$ of ME $/ \mathrm{kg}$ and $19.7 \mathrm{~g}$ of $\mathrm{CP} / \mathrm{kg}$; b. grower diet: 7-12 w= $2854 \mathrm{kcal}$ of ME $/ \mathrm{kg}$ and $17.5 \mathrm{~g}$ of $\mathrm{CP} / \mathrm{kg}$; c. developer diet: 13-15 w= 2777 kcal of ME $/ \mathrm{kg}$ and $16.1 \mathrm{~g}$ of $\mathrm{CP} / \mathrm{kg}$; d. pre-laying diet: $16-17 \mathrm{w}=2797 \mathrm{kcal}$ of $\mathrm{ME} / \mathrm{kg}$ and $16.5 \mathrm{~g}$ of $\mathrm{CP} / \mathrm{kg}$; and e. laying diet: $\geq 18 \mathrm{w}=2814 \mathrm{kcal}$ of ME $/ \mathrm{kg}$ and $18.4 \mathrm{~g}$ of $\mathrm{CP} / \mathrm{kg}$ ). Self-selection feed= (1) the control feed; (2) HEHP (high energy-high protein diet (3101 $\mathrm{kcal}$ of ME/kg and $23.0 \mathrm{~g}$ of CP/kg); (3) HELP (high energy-low protein diet (3133 kcal of ME/kg and $14.3 \mathrm{~g}$ of CP/kg); (4) LEHP (low energy-high protein diet (2638 kcal of ME $/ \mathrm{kg}$ and $23.4 \mathrm{~g}$ of CP/kg); (5) LELP (low energy-low protein diet (2677 kcal of ME/kg and $14.6 \mathrm{~g}$ of CP/kg).

Table 7. Correlation between energy ( $\mathrm{kcal}$ of $\mathrm{ME} / \mathrm{kg})$ and protein $(\mathrm{g} / \mathrm{kg})$ with body weight gain $(\mathrm{g})$.

\begin{tabular}{|c|c|c|c|c|c|c|c|c|}
\hline \multirow{2}{*}{ Period } & \multicolumn{4}{|c|}{ Control } & \multicolumn{4}{|c|}{ Choice } \\
\hline & Energy & BWG & Correlation & Sig. & Energy & BWG & Correlation & Sig. \\
\hline Starter & 2910 & 58.8 & -0.231 & 0.659 & 3026 & 58.7 & 0.909 & 0.011 \\
\hline Grower & 2854 & 84 & -0.777 & 0.068 & 3081 & 85.3 & 0.257 & 0.622 \\
\hline Developer & 2777 & 58.2 & 0.922 & 0.252 & 3091 & 64 & 0.083 & 0.946 \\
\hline Pre-laying & 2809 & 51.5 & 0.658 & 0.108 & 3073 & 57.5 & 0.461 & 0.297 \\
\hline & $\mathrm{CP}$ & BWG & Correlation & Sig. & $\mathrm{CP}$ & BWG & Correlation & Sig. \\
\hline Starter & 197.2 & 58.8 & -0.642 & 0.168 & 188.4 & 58.7 & -0.819 & 0.046 \\
\hline Grower & 174.5 & 84 & 0.362 & 0.481 & 183.8 & 85.3 & 0.396 & 0.436 \\
\hline Developer & 161.1 & 58.2 & 0.922 & 0.252 & 184.8 & 64 & -0.908 & 0.274 \\
\hline Pre-laying & 178.44 & 51.5 & 0.658 & 0.108 & 188.5 & 57.5 & 0.325 & 0.476 \\
\hline
\end{tabular}

Note: $\mathrm{BWG}=$ body weight gain; $\mathrm{CP}=$ crude protein. 

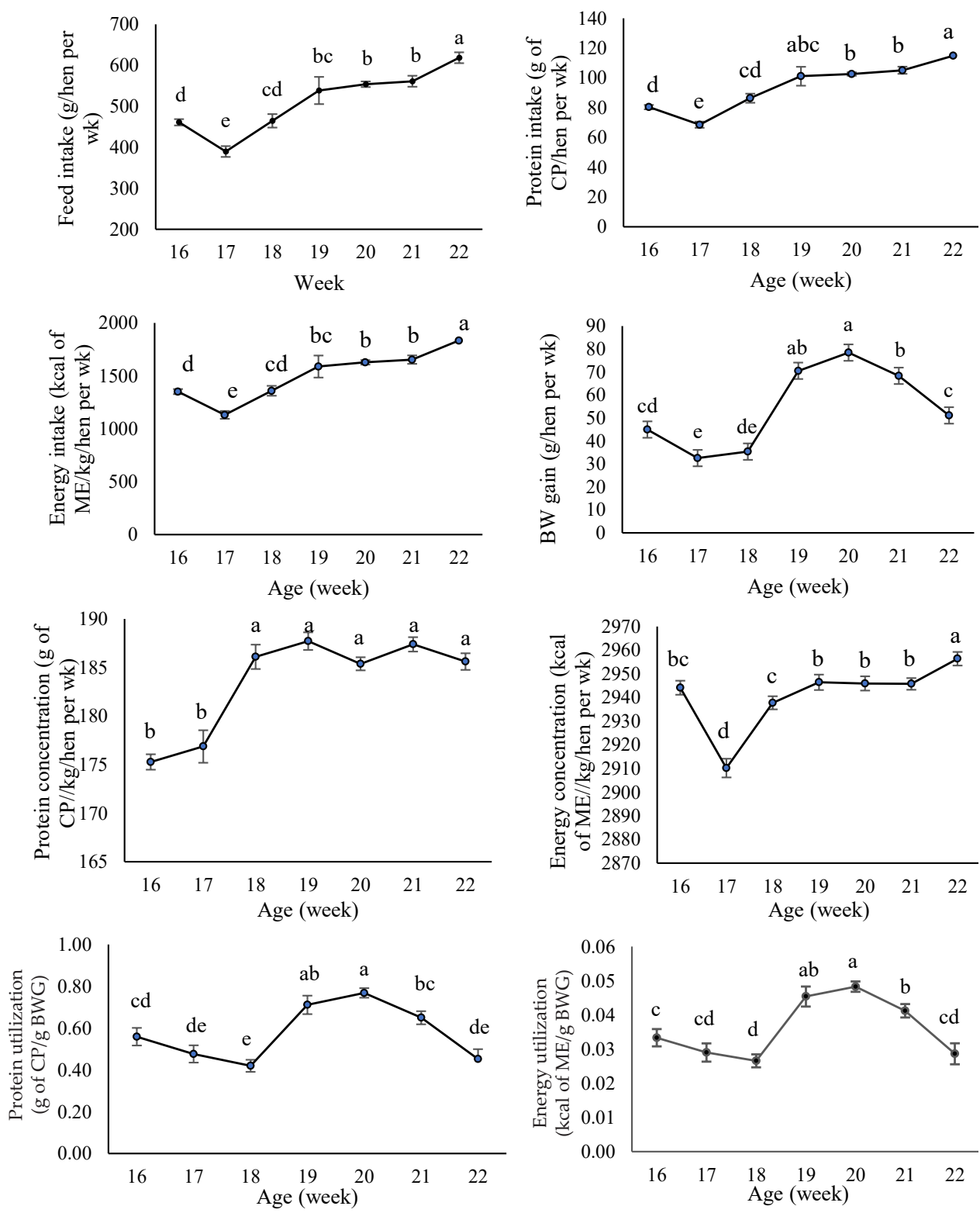

Figure 7. Least square means for traits that show a significant week effect in pre-laying period. Means without a common letter $(a-e)$ differ significantly $(\mathrm{p}<0.05)$.

to a higher concentration of $\mathrm{CP}$ and ME in the ingested feed in all periods (Table 3, 4, 5, and 6). This result agrees with another study in the broiler that feeds intake decreased with the increased protein and lipid concentrations in the broiler diet. Dietary protein and lipid concentration had a more pronounced impact on feed intake than starch, and feed intakes were reduced with the increased protein concentrations (Liu et al., 2016; Khoddami et al., 2018). The birds will reduce protein intake under a high-temperature condition to avoid the heat load (Syafwan et al., 2011). Higher lipid concentration reduces feed intake causing 'ileal brake' triggered by the lipid. Gastrointestinal motility modulates and delays gastric emptying by decreasing the frequency of the gastric cycle, increasing duodenogastric refluxes, and elongating the migrating myoelectric complex when the intraluminal infusion with lipids (Khoddami et al., 2018).
Although the hens on the choice-fed diets consumed much less feed, overall CP and ME intakes were similar to those offered the control diet in all periods. The preferences of the hens to diet to meet the CP and ME requirements during the whole period were higher from HEHP diet (41.59\%), HELP diet (41.37\%), and control diet $(11.79 \%)$ and lower from LEHP diet $(2.69 \%)$ and LELP diet $(2.56 \%)$ (Figure 9$)$. The shifted preference to a high-energy diet was also observed in broilers at high temperatures (Syafwan et al., 2012). The higher preference for a high-energy diet and lower preference for a high-CP diet suggest that the hens have an ability to adjust the nutrients' needs. Such an ability was observed by Fanatico et al. (2013), where the dietary low CP feedstuff-fed broiler chickens were able to gain some nutrients from the scavenging yard emulating the final body weights of the dietary 20\% CP-fed chickens. Capability in adjusting energy intake by consuming 

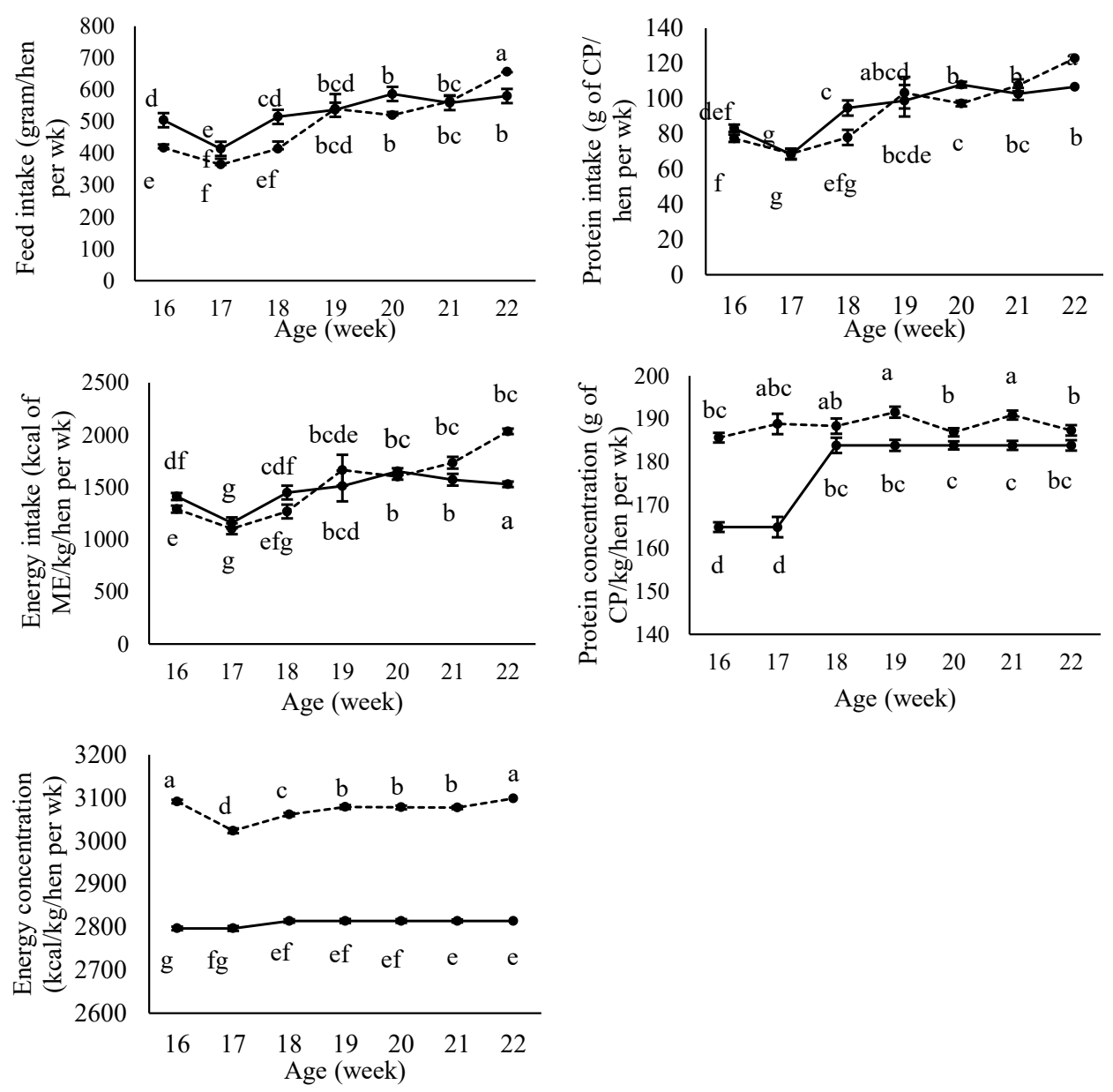

Figure 8. Least square means for traits that show a significant dietary treatments and week interaction in pre-laying period. Means within and between lines without a common letter $(\mathrm{a}-\mathrm{g})$ differ significantly $(\mathrm{p}<0.05)$. Control diet (a. starter diet: 0-6 w= $2910 \mathrm{kcal}$ of ME $/ \mathrm{kg}$ and $19.7 \mathrm{~g}$ of CP $/ \mathrm{kg}$; b. grower diet: 7-12 $\mathrm{w}=2854 \mathrm{kcal}$ of ME/ $\mathrm{kg}$ and $17.5 \mathrm{~g}$ of $\mathrm{CP} / \mathrm{kg}$; c. developer diet: $13-15 \mathrm{w}=2777 \mathrm{kcal}$ of $\mathrm{ME} / \mathrm{kg}$ and $16.1 \mathrm{~g}$ of $\mathrm{CP} / \mathrm{kg}$; d. pre-laying diet: $16-17 \mathrm{w}=2797 \mathrm{kcal}$ of $\mathrm{ME} / \mathrm{kg}$ and $16.5 \mathrm{~g}$ of $\mathrm{CP} / \mathrm{kg}$; and e. laying diet: $\geq 18 \mathrm{w}=2814 \mathrm{kcal}$ of ME $/ \mathrm{kg}$ and $18.4 \mathrm{~g}$ of $\mathrm{CP} / \mathrm{kg}$ ). Choice diet $=(1)$ the control diet, (2) HEHP (high energy- high protein diet (3101 kcal of ME/kg and $23.0 \mathrm{~g}$ of $\mathrm{CP} / \mathrm{kg}$ ), (3) HELP (high energy-low protein diet (3133 kcal of ME $/ \mathrm{kg}$ and $14.3 \mathrm{~g}$ of CP/kg), (4) LEHP (low energy-high protein diet (2638 $\mathrm{kcal}$ of ME/ $\mathrm{kg}$ and $23.4 \mathrm{~g}$ of $\mathrm{CP} / \mathrm{kg}$ ), or (5) LELP (low energy-low protein $\operatorname{diet}(2677 \mathrm{kcal}$ of ME/kg and $14.6 \mathrm{~g}$ of CP/kg). Control (-・- ); Self-selection (---•---).

more of a high-energy diet has also been reported in broiler chickens when given free choice feeding (Syafwan et al., 2012).

Bodyweight gain of female Arabic hens was higher when they consumed a high concentration of $\mathrm{CP}$ as was found in the choice-fed hens (Table $2 b-d$ ). The higher growth rate of chickens was also observed when they consumed a high-protein diet (Fanatico et al., 2016). The effect of dietary protein on the growth rate of broiler chickens was affected by the concentration of lipid in the diet (Liu et al., 2017). It seems that female Arabic hens in our study were tolerant in a high cyclic ambient temperature, although they consumed a higher concentration of $\mathrm{CP}$ than the standard concentration of $\mathrm{CP}$ in the control diet. Since the temperature in the barn followed the natural cyclic temperature, the hens could make some advantages of nutrients for growth by the time of the day less stressful. The bodyweight of broilers was lower when they were kept at a constant high temperature than when they were kept at a high cyclic temperature and reduced meat quality (Quinteiro-Filho et al., 2010; Zhang et al., 2012).

Treatments had a very significant effect on $\mathrm{CP}$ and ME concentrations of the diet consumed by the hens (Table 2a-d). Those given a choice to feed could likely maintain its CP need (on average: 186.7 vs. $180.1 \mathrm{~g} /$ $\mathrm{kg}$; $\mathrm{p}<0.001)$. Regarding the dietary ME concentration, Tables 3, 4, 5, and 6 depicted that the ME in the diet consumed by the choice group of hens was higher than those by the control group of hens (on average: 3065 $\mathrm{kcal}$ of $\mathrm{ME} / \mathrm{kg}$ vs. $2844 \mathrm{kcal} / \mathrm{kg} ; \mathrm{p}<0.001)$. These data support the fact that hens were able to select diets containing nutrients of their needs. The higher $\mathrm{CP}$ and $\mathrm{ME}$ concentrations of the feed consumed by self-selection group than by the control group indicated hen's ability to compose available diets to fulfill the requirement of protein and energy. These results reveal that $\mathrm{CP}$ requirement for female Arabic hens is higher after the starter period, and ME requirement is higher from the starter period than in the control diet for Brown Laying hens. 


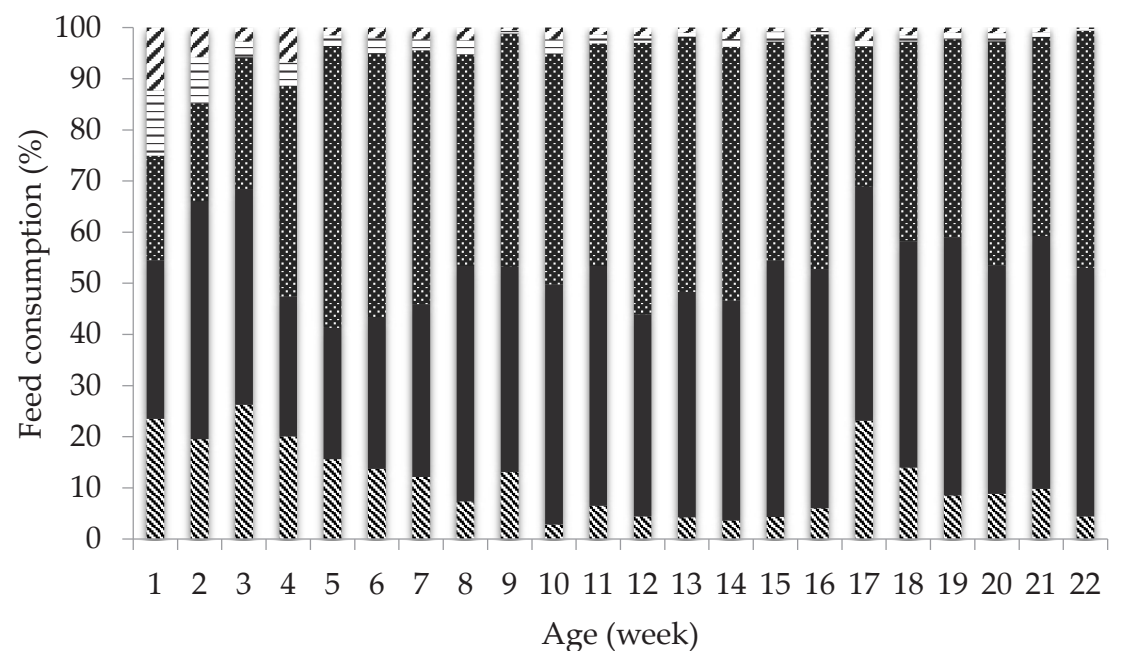

Figure 9. Consumption of a control diet, HEHP (high energy-high protein), HELP (high energy-low protein), LEHP (low energy-high protein) and LELP (low energy-low protein) as a portion of feed intake. Control diet (a. starter diet: $0-6 \mathrm{w}=2910 \mathrm{kcal}$ of $\mathrm{ME} / \mathrm{kg}$ and $19.7 \mathrm{~g}$ of CP $/ \mathrm{kg}$; b. grower diet; 7-12 $\mathrm{w}=2854 \mathrm{kcal}$ of ME $/ \mathrm{kg}$ and $17.5 \mathrm{~g}$ of $\mathrm{CP} / \mathrm{kg}$; c. developer diet: $13-15 \mathrm{w}=2777 \mathrm{kcal}$ of $\mathrm{ME} / \mathrm{kg}$ and $16.1 \mathrm{~g}$ of $\mathrm{CP} / \mathrm{kg}$; d. pre-laying diet: 16-17 $\mathrm{w}=2797 \mathrm{kcal}$ of $\mathrm{ME} / \mathrm{kg}$ and $16.5 \mathrm{~g}$ of $\mathrm{CP} / \mathrm{kg}$; and e. laying diet: $\geq 18 \mathrm{w}=2814 \mathrm{kcal}$ of ME $/ \mathrm{kg}$ and $18.4 \mathrm{~g}$ of $\mathrm{CP} /$ $\mathrm{kg}$ ). Choice diet $=(1)$ the control diet, (2) HEHP (high energy- high protein diet (3101 kcal of ME/kg and 23.0 $\mathrm{g}$ of $\mathrm{CP} / \mathrm{kg}$ ), (3) HELP (high energy-low protein diet (3133 kcal of ME/kg and $14.3 \mathrm{~g}$ of CP/kg), (4) LEHP (low energy-high protein diet (2638 kcal of ME/kg and $23.4 \mathrm{~g}$ of CP/ $\mathrm{kg}$ ), or (5) LELP (low energy-low protein diet

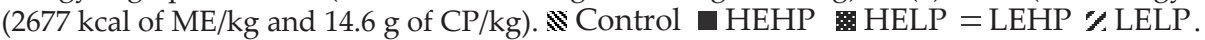

Assessment of efficiency of protein and energy utilization enables a better understanding of the effect of dietary treatments beyond insights that grow. The utilization of $\mathrm{CP}$ and ME in this study was similar between the choice-fed hens and the control-fed hens. Every week, the decline in protein and energy efficiency ratio was due to the decline in $\mathrm{BW}$ gain while the intake of protein and energy increased. The similarity in the utilization of $\mathrm{CP}$ and $\mathrm{ME}$ indicated that the effectivity in utilizing the $\mathrm{CP}$ and $\mathrm{ME}$ in the diet composed by the choice-fed birds was the same as the control diet. The higher the protein and energy efficiency ratio, the more efficient the hens in utilizing the protein and energy consumed. The higher protein in the diet could mean that the smaller protein ratio resulted in a significant effect on the value of protein efficiency ratio (Sari et al., 2014).

The onset of laying of Arabic hens in this study (10\% of egg production) occurred on the $6^{\text {th }}$ day of 21 weeks of age in the choice-fed group and on the $1^{\text {st }}$ day of 22 weeks of age in the control-fed group. Although three units of experiment in the control-fed group did not produce egg until the 1st day of 22 week of age, one unit of these three units was not laying an egg until the $6^{\text {th }}$ day of 22 weeks of age. So, the choice-fed group was mature two days earlier than the control-fed group. Therefore, the pre-laying period of Arabic hen is not the same as the White Leghorn hen, which occurred at 18 weeks of age. The faster age at point of laying of hens offered a choice diet could be related to the higher $\mathrm{CP}$ and $\mathrm{ME}$ concentrations in the diet consumed. Based on BW gain of this study, the ME $(\mathrm{kcal} / \mathrm{kg})$ and $\mathrm{CP}(\mathrm{g} / \mathrm{kg})$ requirements for Arabic laying hens during the rearing period are as the following: Starter (1 to 6 weeks): 3026 and 188.4; Grower (7 to 12 week): 3081 and 183.9;
Developer (13 to 15 week): 3091 and 184.8; and Prelaying (16 to 22 week): 3073 and 188.5. Therefore, CP requirement (in terms of $\mathrm{g} / \mathrm{kg}$ in the diet consumed) for starter period was lower $(\mathrm{p}<0.001)$ and for other periods were higher $(\mathrm{p}<0.001)$, while ME requirement (in term of $\mathrm{kcal} / \mathrm{kg}$ in the diet consumed) was higher $(\mathrm{p}<0.001)$ for all rearing periods than Hy-line management guide 2011.

ME level of control dietary treatment has a small and a strong negative correlation with BWG during a starter and grower period and a strong positive correlation during the developer and pre-laying period. On the other hand, ME level of choice dietary treatment has a strong positive correlation during a starter and a very small positive correlation during developer periods. A small and medium positive correlation has occurred during the grower and pre-laying periods. $\mathrm{CP}$ level of control dietary treatment has a strong negative correlation during a starter period and a medium to strong positive correlation from grower to pre-laying periods. In contrast, $\mathrm{CP}$ level of choice dietary treatment has a strong negative correlation during starter and developer periods and a medium positive correlation during the grower and pre-laying periods.

\section{CONCLUSION}

Free choice feeding on a diet varying in energy and protein had a beneficial effect on the growth rate of female Arabic hens by consuming a more high energyhigh protein and high energy-low protein diet. ME and $\mathrm{CP}$ requirements of Arabic Arab hens for starter period were $3026 \mathrm{kcal}$ of $\mathrm{ME} / \mathrm{kg}$ and $18.8 \%$, for grower period were $3081 \mathrm{kcal}$ of $\mathrm{ME} / \mathrm{kg}$ and $18.4 \%$, for developer period were $3091 \mathrm{kcal}$ of $\mathrm{ME} / \mathrm{kg}$ and $18.5 \%$, and for pre- 
laying period were $3072 \mathrm{kcal}$ of $\mathrm{ME} / \mathrm{kg}$ and $18.8 \%$ to faster the onset of laying.

\section{CONFLICT OF INTEREST}

None of the authors of this work has financial or other relationships with people or organizations that could influence inappropriately or bias on the contents of this paper.

\section{ACKNOWLEDGEMENT}

The authors would like to thank the Rector of Jambi University and the Head of Research and Community Services Institute of Jambi University for providing funds for this research

\section{REFERENCES}

Cruz, V., A. Pezzato, D. Pinheiro, J. Gonçalves, \& J. Sartori. 2005. Effect of free-choice feeding on the performance and ileal digestibility of nutrients in broilers. Rev. Bras. Ciência Avícola 7:143-150. https://doi.org/10.1590/ S1516-635X2005000300002

Daghir, N. J. 2008. Nutrient Requirements of Poultry at High Temperatures.Pages 133-316 in Poultry Production in Hot Climates. Daghir, N.J., ed. $2^{\text {nd }}$ ed. CAB International, Cromwell Press, Trowbridge. https://doi. org/10.1079/9781845932589.0000

Director General of Livestock and Animal Health. 2019. Livestock and Animal Health Statistics. Director General of Livestock and Animal Health Service, Ministry of Agriculture, Jakarta.

Fanatico, A. C., V. B. Brewer, C. M. Owens-Hanning, D. J. Donoghue, \& A. M. Donoghue. 2013. Free-choice feeding of free-range meat chickens. J. Appl. Poult. Res. 22:750-758 . https://doi.org/10.3382/japr.2012-00687

Fanatico, A. C., C. M. Owens-Hanning, V. B. Gunsaulis, \& A. M. Donoghue. 2016. Choice feeding of protein concentrate and grain to organic meat chickens. J. Appl. Poult. Res. 25:156-164. https://doi.org/10.3382/japr/pfv076

Hartawan, R., \& N. L. P. I. Dharmayanti. 2016. The Meq Gene Molecular Profile of Marek's Disease Virus Serotype 1 From Kampung and Arabic Chicken Farms in Sukabumi, West Java, Indonesia. HAYATI J. Biosci. 23:160-167. https:// doi.org/10.1016/j.hjb.2016.12.004

He, S. P., M. A. Arowolo, R. F. Medrano, S. Li, Q. F. Yu, J. Y. Chen, \& J. H. He. 2018. Impact of heat stress and nutritional interventions on poultry production. Worlds. Poult. Sci. J. 74:647-664. https://doi.org/10.1017/S0043933918000727

HyLine. 2011. Hy-line Brown Commercial Management Guide. Hy-Line, Australia.

Khoddami, A., P. V. Chrystal, P. H. Selle, \& S. Y. Liu. 2018. Dietary starch to lipid ratios influence growth performance, nutrient utilisation and carcass traits in broiler chickens offered diets with different energy densities (C Óvilo, Ed.). PLoS One. 13:e0205272. https://doi.org/10.1371/journal. pone.0205272

Kristina Dewi, G. A. M., I. G. Mahardika, I. K. Sumadi, \& I. M. Suasta. 2015. Effect of dietary energy and protein level on growth performance of native chickens at the starter phase. Khon Kaen Agr. J. 43:206-210.
Littell, R. C., P. R. Henry, \& C. B. Ammerman. 1998. Statistical analysis of repeated measures data using SAS procedures. J. Anim. Sci. 76:1216. https://doi.org/10.2527/1998.7641216x

Liu, S. Y., P. H. Selle, D. Raubenheimer, D. J. Cadogan, S. J. Simpson, \& A. J. Cowieson. 2016. An assessment of the influence of macronutrients on growth performance and nutrient utilisation in broiler chickens by nutritional geometry. Br. J. Nutr. 116:2129-2138. https://doi.org/10.1017/ S0007114516004190

Liu, S. Y., P. H. Selle, D. Raubenheimer, R. M. Gous, P. V. Chrystal, D. J. Cadogan, S. J. Simpson, \& A. J. Cowieson. 2017. Growth performance, nutrient utilisation and carcass composition respond to dietary protein concentrations in broiler chickens but responses are modified by dietary lipid levels. Br. J. Nutr. 118:250-262. https://doi.org/10.1017/ S0007114517002070

Naseem, S., \& A. J. King. 2020. Effect of Lactobacilli on production and selected compounds in blood, the liver, and manure of laying hens. J. Appl. Poult. Res. 29:339-351. https:// doi.org/10.1016/j.japr.2019.11.008

Perween, S., K. Kumar, Chandramoni, S. Kumar, P. K. Singh, M. Kumar, \& A. Dey. 2016. Effect of feeding different dietary levels of energy and protein on growth performance and immune status of Vanaraja chicken in the tropic. Vet. World. 9:893-899. https://doi.org/10.14202/ vetworld.2016.893-899

Quinteiro-Filho, W. M., A. Ribeiro, V. Ferraz-de-Paula, M. L. Pinheiro, M. Sakai, L. R. M. Sá, A. J. P. Ferreira, \& J. Palermo-Neto. 2010. Heat stress impairs performance parameters, induces intestinal injury, and decreases macrophage activity in broiler chickens. Poult. Sci. 89:1905-1914. https://doi.org/10.3382/ps.2010-00812

Raphulu, T., \& C. J. van Rensburg. 2018. Dietary protein and energy requirements of Venda village chickens. J. Agric. Rural Dev. Trop. Subtrop. 119:95-104.

Sari, K. A., B. Sukamto, \& B. Dwiloka. 2014. Protein efficiency of broiler chickens fed with diets containing kayambang leaves meal. Agripet 14:76-83. https://doi.org/10.17969/ agripet.v14i2.1867

Sugiharto, S., T. Yudiarti, I. Isroli, E. Widiastuti, \& E. Kusumanti. 2017. Dietary supplementation of probiotics in poultry exposed to heat stress - A review. Ann. Anim. Sci. 17:591-604. https://doi.org/10.1515/aoas-2016-0062

Syafwan, S., R. P. Kwakkel, \& M. W. A. Verstegen. 2011. Heat stress and feeding strategies in meat-type chickens. Worlds. Poult. Sci. J. 67:653-674. https://doi.org/10.1017/ S0043933911000742

Syafwan, S., G. J. D. Wermink, R. P. Kwakkel, \& M. W. A. Verstegen. 2012. Dietary self-selection by broilers at normal and high temperature changes feed intake behavior, nutrient intake, and performance. Poult. Sci. 91:537-549. https://doi.org/10.3382/ps.2011-01559

Walter, W. S., A. M. George, A. C. Elizabeth, \& D. W. Russel. 2018. SAS for Mixed Models: Introduction and Basic Applications. SAS Institute Inc, Cary, NC.

Wang, W. C., F. F. Yan, J. Y. Hu, O. A. Amen, \& H. W. Cheng. 2018. Supplementation of Bacillus subtilis-based probiotic reduces heat stress-related behaviors and inflammatory response in broiler chickens. J. Anim. Sci. 96:1654-1666. https://doi.org/10.1093/jas/sky092

Zhang, Z. Y., G. Q. Jia, J. J. Zuo, Y. Zhang, J. Lei, L. Ren, \& D. Y. Feng. 2012. Effects of constant and cyclic heat stress on muscle metabolism and meat quality of broiler breast fillet and thigh meat. Poult. Sci. 91:2931-2937. https://doi. org/10.3382/ps.2012-02255 